\title{
Territory and Technology: A Case Study and Strategy from the California Delta
}

\author{
Richard L. Hindle, Neeraj Bhatia
}

\begin{abstract}
The notion of the resilient edge is perhaps most emblematic in deltaic landscapes, which are a landscape form par excellence of edge conditions - both for their fluctuating natural boundaries and complicated relationship with anthropogenic forces. Given this juxtaposition, it is worthwhile to revisit the early history of deltaic transformation and urbanization - from surfaces to edges - to gain insights into the future resilience of these landscapes and strategies for their redesign. In this essay, we investigate the early history of the California Delta, starting with the Swamp Lands Act of 1850, to gain insights into how policy and technology territorialized this vast inland estuary. We then reformulate this history as a contemporary strategy for the design of deltaic landscapes and introduce a pedagogical experiment to test our observations.
\end{abstract}

Keywords: California Delta, design strategies, innovation, Swamp Lands Act, technology and territory

The California Delta, at the convergence of the Sacramento and San Joaquin Rivers, provides a fascinating case study on how technology territorialized the fluctuating boundaries of a dynamic inland estuary and transformed it into an ordered and productive landscape defined by levees, fields, and channels. It is hard to imagine, but the ancestral ecology of the California Delta was not retooled by an orchestrated government masterplan but rather through a bottom-up process of technological innovation and distributed capitol investment. Land grants incentivized private development of the delta, transforming millions of acres of tule 
marsh into a robust, albeit outdated, landscape infrastructure comprised of drainage works, levees, and agriculture. The transformation of the California Delta, and 64 million acres [26 million ha] of swampland throughout fourteen other states, was part of a radical landscape strategy played out on a national scale under the Swamp Land Acts (1849, 1850, 1860). From the initial California Swamp Land Grants of 1850 until the early-twentieth century, more than two million acres [more than $809.000 \mathrm{ha}$ ] of prime wetland were drained and leveed in the California Delta a massive swath of California's interior was reconfigured by investors, inventors, farmers, and speculators, suggesting that the transformation of large-scale landscape systems, and construction of extensive infrastructure, may be accomplished through bottom-up processes with limited government funding or regulation.

The resulting landscape of the California Delta is part-natural, partartificial, and materialized from a collection of specific technologies that, once deployed, had a trans-scalar, although inadvertent, impact on the delta. While mired by a colonial and hegemonic past, we can learn from the history of landscape transformation enacted in the California Delta and other swamplands for the innovations they inspired. As we face a gridlocked federal government and rapid environmental change that no single agency is equipped to respond to, this bottom-up approach provides a useful template for reimagining the future of this dynamic territory.

Given the convergence of environmental challenges that currently threaten the delta, can a similar strategy of socio-technical innovation and entrepreneurialism that was used to transform the delta to an agricultural landscape in the late nineteenth century facilitate the renewed productivity, reconstruction, and possible re-wilding in the twenty-first?

THE SWAMP LAND ACTS (1849, 1850, 1860): A NINETEENTH CENTURY STRATEGY FOR ENVIRONMENTAL TRANSFORMATION

The California Delta region exemplifies the transformations of the American landscape enacted as the west transitioned from distant territories to states. This region was largely developed for its fertile soils, protected navigation corridors, abundance of fresh water, and proximity to rapidly urbanizing areas such as the cities of San Francisco and Sacramento. One of the first organized attempts to colonize the Delta came in the form of "An Act to enable the state of Arkansas, and other States to reclaim the 'swamp lands' within their limits" (September 28, 1850), which was part of series of initiatives popularly known as the Swamp Land Acts (1849, 1850, 1860). ${ }^{1,2}$ The reclamation of swamplands catalyzed investment in previously unwanted federal lands - changing settlement patterns, displacing native cultures, and also catalyzed technological innovation and private investment through non-cash incentives known as land grants. ${ }^{3}$ 


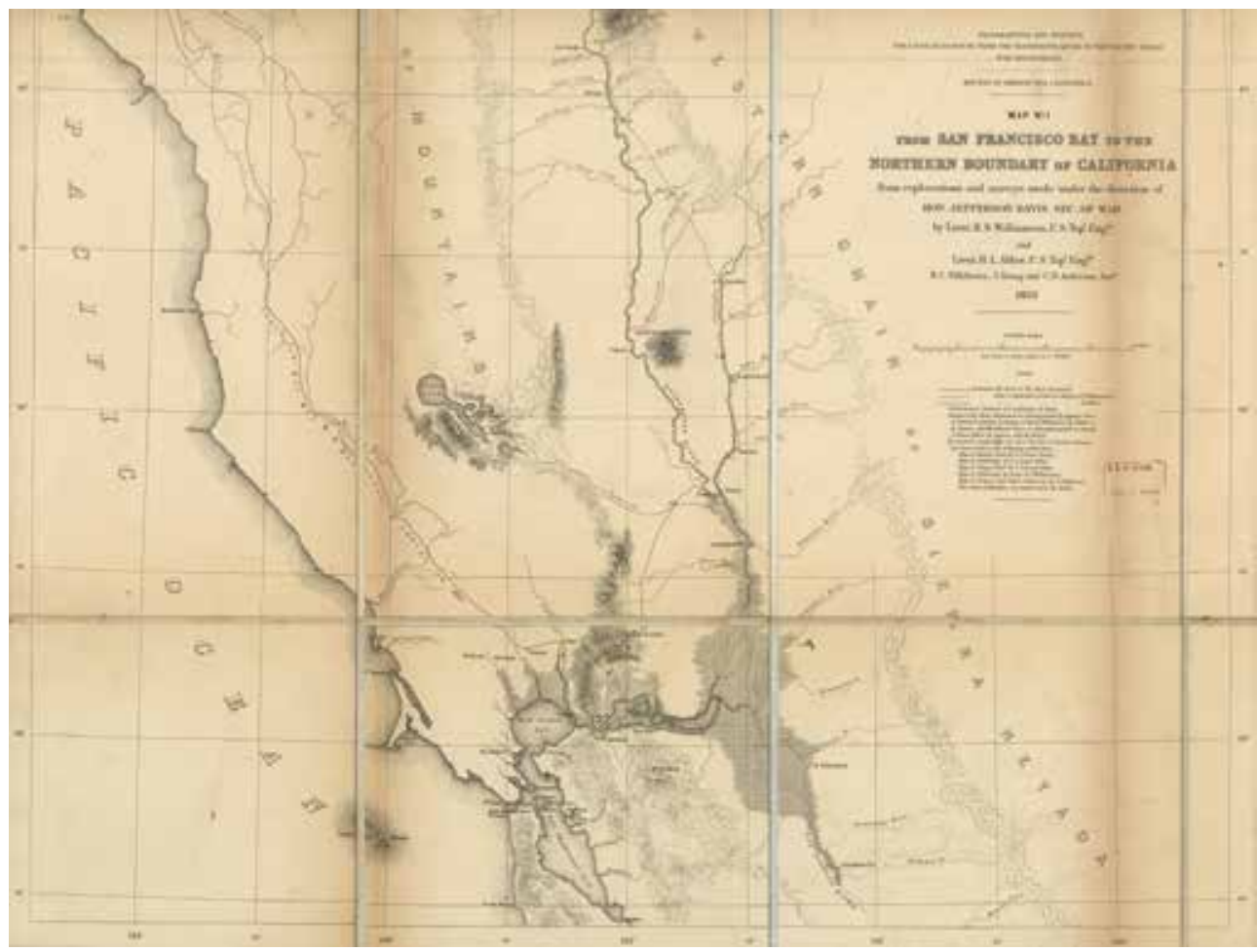

Figure 1. Map showing the topography and waterways of the state, including the vast inland estuary known as the California Delta, ca. 1885.

The first Act (also known as "Swamp Land Grant"), titled "An Act to aid the State of Louisiana in draining the Swamp Lands therein" was passed by Congress in 1849, "to aid the State in constructing the necessary levees and drains to reclaim the swamp and overflowed lands therein, the whole of those swamp and overflowed lands, which may be, or are, found unfit for cultivation, shall be, and the same are hereby, granted to that State." The act transferred 9,493,456 acres [3.841.868 ha] of federally owned swamp to the state of Louisiana, contingent on the sale and reclamation of the property, and the use of funds resulting from the sale to build levees along the Mississippi river and its adjacent tributaries and distributaries. It is with this policy mechanism that the first federally backed levees were constructed along the Mississippi using the capital and sweat equity of private citizens (and their slaves) coupled with the disposal of lands in the public domain.

The second Act of 1850, "An Act to enable the state of Arkansas, and other States to reclaim the 'swamp lands within their limits'," expanded the precedent established in Louisiana to Arkansas, Alabama, California, Florida, Illinois, Indiana, lowa, Michigan, Mississippi, Missouri, Ohio, and Wisconsin, ultimately transferring 50,409,348 acres [20.399.957 ha] of wetland to the states. In California, 2,192,975 acres [887.466 ha] were transferred to the state for sale and reclamation, consisting mostly of extensive tule marsh in the Central Valley, what is today known as the California Delta (Fig. 1). 
The third Act passed in 1860, transferring 5,002,611 acres [2.024.486 ha] to Minnesota and Oregon. ${ }^{4}$

Collectively, the three acts of Congress shifted $64,895,415$ acres [26.262.266 ha] from federal public domain to the states so that private citizens and eventually reclamation companies would improve these areas. ${ }^{5,6}$ States served only as intermediaries for the sale of land to private landowners who were ultimately responsible for improving the land, and any leftovers too difficult to reclaim would remain property of the state. In true American style, individual landowners and corporations became default infrastructuralists; building the levees, installing the drains, and edifying the countries' most extensive water infrastructure in a freewheeling manner premised on radical environmental transformation and profit with limited government intervention. When evaluated through a contemporary lens, the Swamp Land Acts represent a radical, if fraught, landscape strategy that reified a diffuse network of infrastructure though millions of acres of difficult swampland. Despite the well-known issues that emerged through these acts - the displacement of indigenous cultures, loss of ancestral wetlands, riparian zones, and vernal pools - it is worthwhile revisiting the radical potentiality of a strategy that mobilized citizens to enact the flood and drainage infrastructure through millions of acres of seemingly impenetrable swamp. Today, this convergence of factors promises to repeat itself with perennial budget deficits, gridlock, and looming environmental threats from sea level rise and unprecedented storm events - the impacts of which will reverberate across the United States and around the world. Most importantly, no single government institution, corporation, or citizen group, is prepared to respond or plan for such wide spread environmental challenges, as we have observed with continual flooding in hurricane-prone states, most recently in Houston with Hurricane Harvey.

\section{FRONTIER AS A SOCIO-TECHNICAL PROCESS: EVIDENCE FROM THE CALIFORNIA DELTA}

Only days after gaining statehood on September 9, 1850, the Swamp Lands Act of September 28, 1850, had transferred over two million acres [more than 809.000 ha] of Federally owned swamp to California. Failures of terminology, ambiguous mappings, finance, and policy at the State and Federal level bungled much of the process, leading to piecemeal reclamation riddled with corruption. Yet even without a coherent plan, the amorphous landscape of the delta was altered irreparably by the imposition of anthropogenic delineations created by mechanical devices ${ }^{7}$ (Fig. 2). Just as the plow broke the plains, the clamshell and hydraulic dredges invented in the mid-nineteenth century broke the thick, wild, tule of the delta. Once designated a swampland, the delta was reimagined as arable, ordered, and productive landscape that was maintained by leveed edges and elaborate drainage, designed to retool the native ecology and displace indigenous cultures. ${ }^{8}$ The designation of California's inland delta as a swamp recast it as a frontier - one of the last pieces of ground to be colonized on the 
migrating edge of a vast western territory that had already reached its western boundary at the Pacific Ocean.

While enabled by a loosely coordinated federal policy, the project of reclamation, or territorialization, in the delta was reified through technological innovation and the resourcefulness of the enterprising settlers and prospecting urbanites. The technological innovation that emerged from this migrating frontier boundary, however, is no coincidence. According to Fredrick Jackson Turner's "frontier thesis," this type of hinterland was essential to development of America, helping to propel migrants into evermore-distant terrains. Settlers that pushed westward had free land at their disposal and developed skills to control and profit from the "wild" natural environment. The frontier embodied the tension between "civilized" settlements and the "wilderness" beyond, and it was precisely this edge condition that Turner viewed as beneficial, as he states:

"For a moment, at the frontier, the bonds of custom are broken and unrestraint is triumphant. There is not tabula rasa. The stubborn American environment is there with its imperious summons to accept its conditions; the inherited ways of doing things are also there; and yet, in spite of environment, and in spite of custom, each frontier did indeed furnish a new field of opportunity." 9

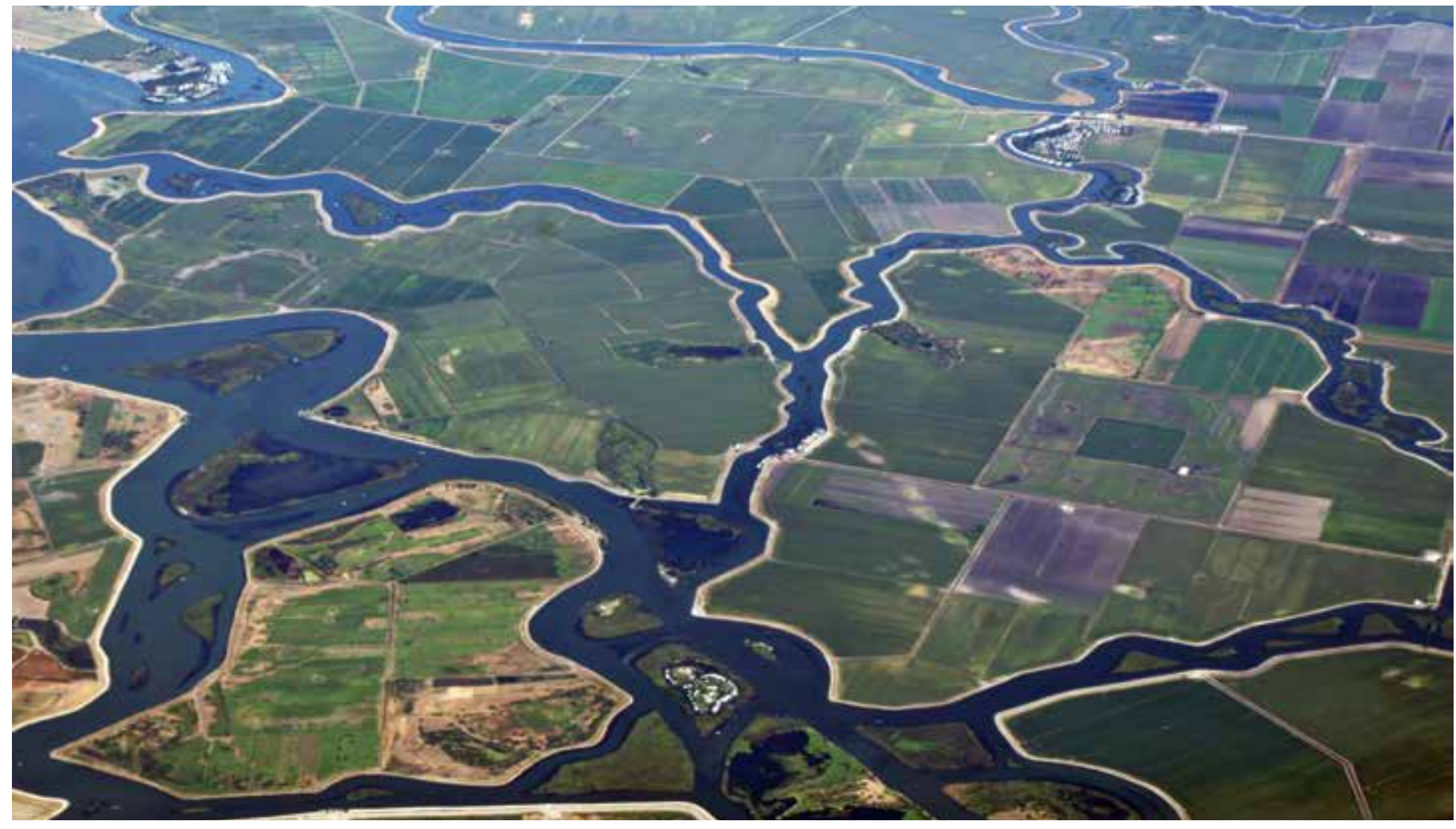

Figure 2. Aerial View of the California Delta showing levees, agricultural land, and patches of remnant wetlands. 
The frontier became such a force of individual enterprise as it expanded, that the legislation of the National Government became conditioned on the frontier itself. ${ }^{10} \mathrm{~A}$ distinct and complex coupling was transpiring on the frontier as individuals here needed to reconcile the local context - both environmental and cultural - with collective national policy and economic trade. These conditions facilitated land prospecting, entrepreneurialism, and innovation in the delta.

Although plagued by a reprehensible past of ecological degradation and cultural displacement, the wilderness of American swamplands became a catalyst for innovation, a point that is vividly illustrated in the California Delta. For most of the delta's early history, individuals, not the State, reclaimed the landscape for agriculture. ${ }^{11}$ Landowners were responsible for its productivity and deployed, as well as imagined, new dredging machines, levees, drains, machinery, and pumps to convert a vast estuarine landscape into agricultural land. Despite the radical inventiveness, we know little about the liminal space between the environmental imagination of the settler and unmediated wilderness. Many early settlers were not those we typically associate with representing their imaginative visions, such as writers or artists. The frontier of California's wilderness was the infrastructural space of salesmen, entrepreneurs, homesteaders, and bandits among others, whose resourcefulness made them inventors and whose imagination is arguably best documented in land records, court transcripts, business dossiers, newspaper clippings, exploits of the physical environment, and the patent archive.

\section{ENVIRONMENTAL IMAGINATION THROUGH TECHNOLOGICAL INNOVATION}

The environmental imagination takes many forms. In art and literature, representations of nature explicate the complex historical relations among humans and the environments we inhabit. ${ }^{12}$ The environmental imagination may also be traced through technological innovation, which developed most forcefully along the frontier and is depicted within the annals of the patent office. Buckminster Fuller, the famed architect and inventor, summarizes the process as such:

"When the democratic idea broke loose in Europe, as a result of partial emancipation of man by his artist-an-scientist devised mechanisms, the popular representatives of that time, thinking by habit in terms of feudal structure and laboring under the problem of transferring privilege of sovereignty to the populace, deemed it a wise and just act to embody the 'letters patent' idea in their democratic constitution... The necessity of invention and growth were highly apparent to the budding democracies, for had not invention itself forwarded man to the possibility of emergent Democracy?" 13 
Technological innovation became a mechanism to civilize the land and also to democratize it. In this context, the text and images within patent documents reveal a vivid environmental imagination of diverse individuals, and view of the natural world distinct, though not dissimilar, from other representations found in art, literature, and science.

Within patents, we find the specific mechanisms developed along the frontier as the wilderness was transformed and territorialized, not only in the Sacramento-San Joaquin Delta, but all across the United States. These technologies operated on the theoretical edge of the frontier and also quite literally the riparian edges of the delta-transforming this dynamic landscape into a series of static "islands." The first levees in this new territory were built in the 1850-60s, essentially transferring levee construction methods developed in Europe and in the Louisiana Territory to the California Delta. ${ }^{14}$ Methods for building levees in the Southern United States were not suited to the unique conditions of the California Delta, with its deep organic soils, thick tule, and cold freshets from the Sierra Nevada Mountains. This necessitated technological innovation, especially as slavery was outlawed in the western United States as part of the Compromise of $1850 .{ }^{15}$ For instance, inventors such as Allexy W. Von Schmidt, John Hatch, and others developed hydraulic and clamshell dredges to levee reclaimed land and adapt to the delta's environmental contingencies (Figs. 3, 4). Dredge technologies such as these built most of the delta's leveed edges and entirely reconfigured the geomorphology of the region; ${ }^{16}$ and, as the levees proliferated and were built higher, so too were the dredge boats that operated in the region.

Figure 3. Invented in San Francisco, California (1876) by Allexy W. Von Schmidt, this invention imagined a process of removing sand and mud from river channels through hydraulic mining processes. The machine and process utilize an innovative cutter-head to agitate bottom sediments to remove the material through suction. Hydraulic dredges were replaced by clamshell dredges, which allowed for a more precise placement of material.

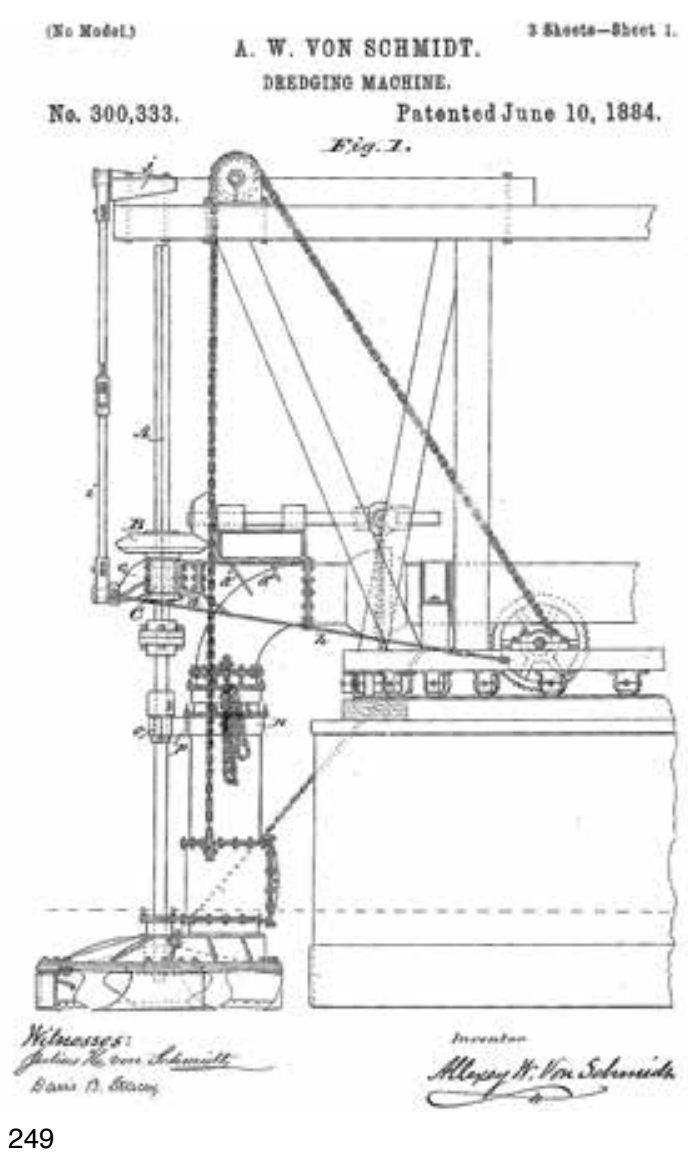


In this period of radical environmental imagination inventors from across California developed machines to transform the water works of the state, and sought patents to protect their intellectual property essentially conflating innovation and environment through patent rights. Entrepreneurial prospectors developed methods to irrigate, drain, and cultivate lands in the frontier swamplands in the hopes of urbanizing the distant frontiers of the valley. For example, in areas with perched water tables, William Osterberg (Fig. 5) of Modesto California developed a

(No Model.)

No. 485,193
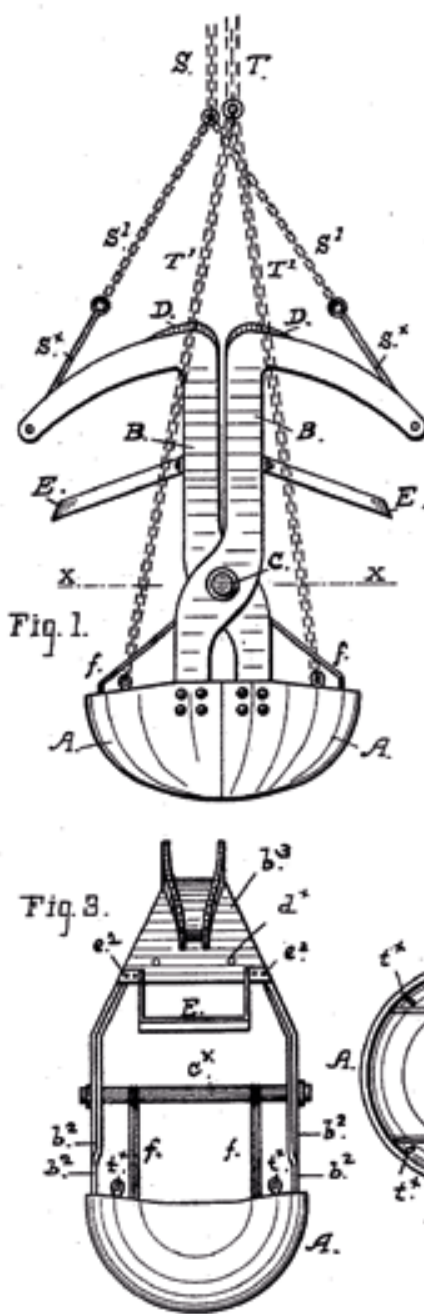

Witnesses:

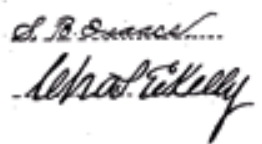

\section{J. HATCH.}

DREDGING IMPLEMENT.

Patented Nov. 1, 1892.

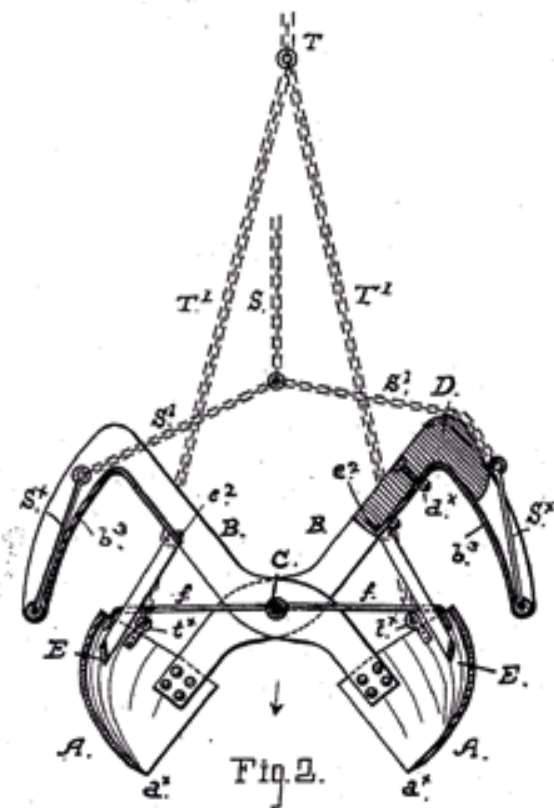

Fin. 2 .

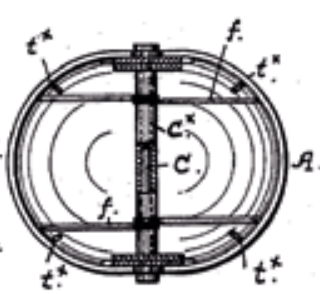

Fig. 4.

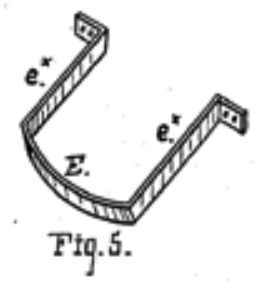

Figure 4. Invented in San Francisco, California, by John Hatch. The clamshell dredge is the most important technology to have transformed the delta. 
W. AND M. OSTERBERG

SYSTEM FOR DRAINING LAND.

APPLICATION FHLE HAR, $1,1912$.

$1,432,489$.

Patented Oet. 17, 1922.
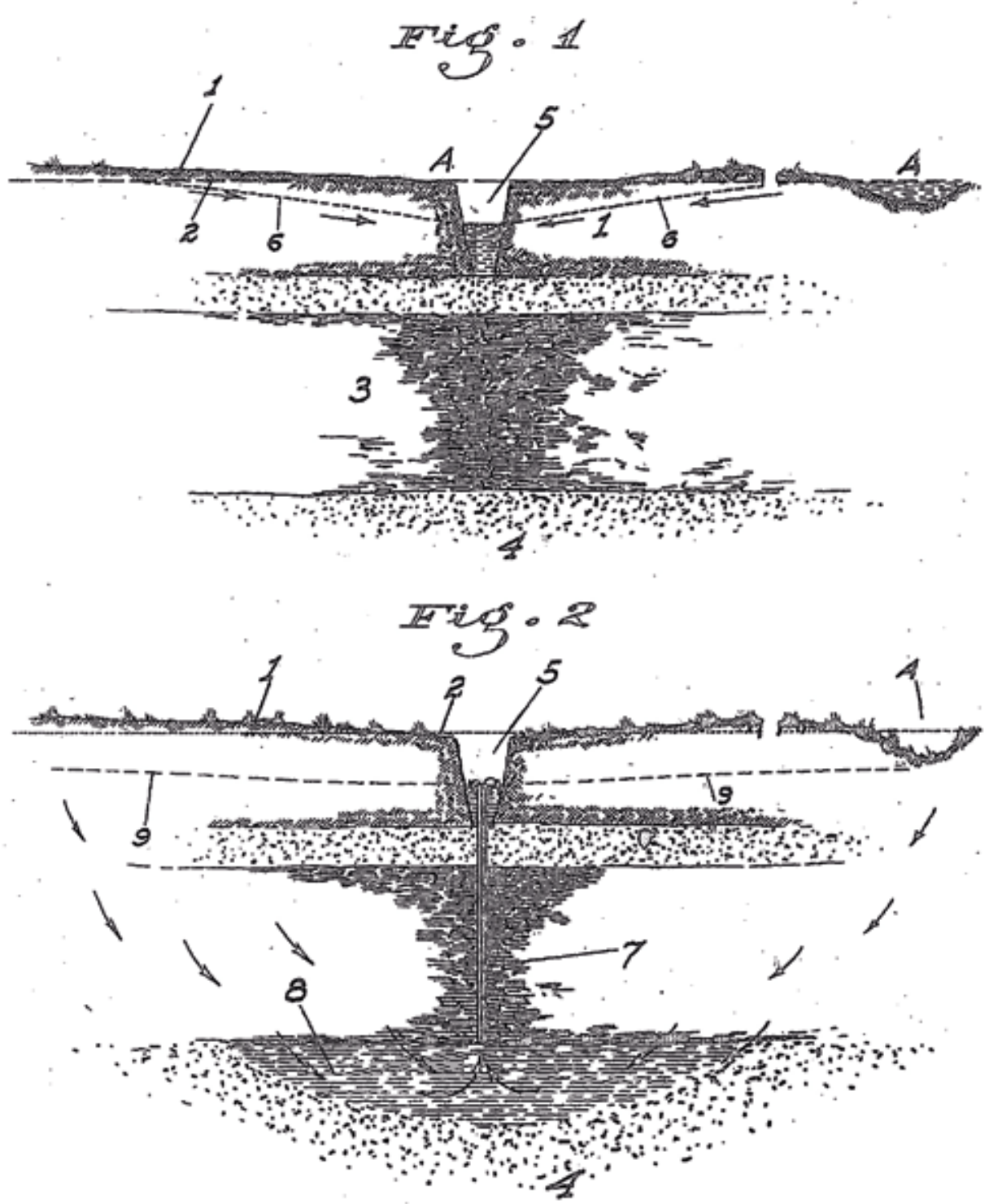

INVENTORS

Willian Osterbers on

Meurrits asterberg ar Bingedilatom ATTORNEY

Figure 5. Invented in Modesto, California (1922), William and Maurits Osterberg imagined a "System of Draining Land" which expedites the movement of groundwater to the surface through a series of wells and channels using the passive forces of water pressure and gravity. Groundwater would gradually be lowered, drying the land in preparation for cultivation, and altering the ecology. 
patented system to drain lowlands by drawing water to the surface through a series of wells and channels, passively lowering the water table in a given area. And in areas with soft organic soils, Benjamin Holt invented the caterpillar tractor specifically to traverse the soft ground of the Delta (Fig. 6). Similarly, in areas dependent on groundwater from the inland
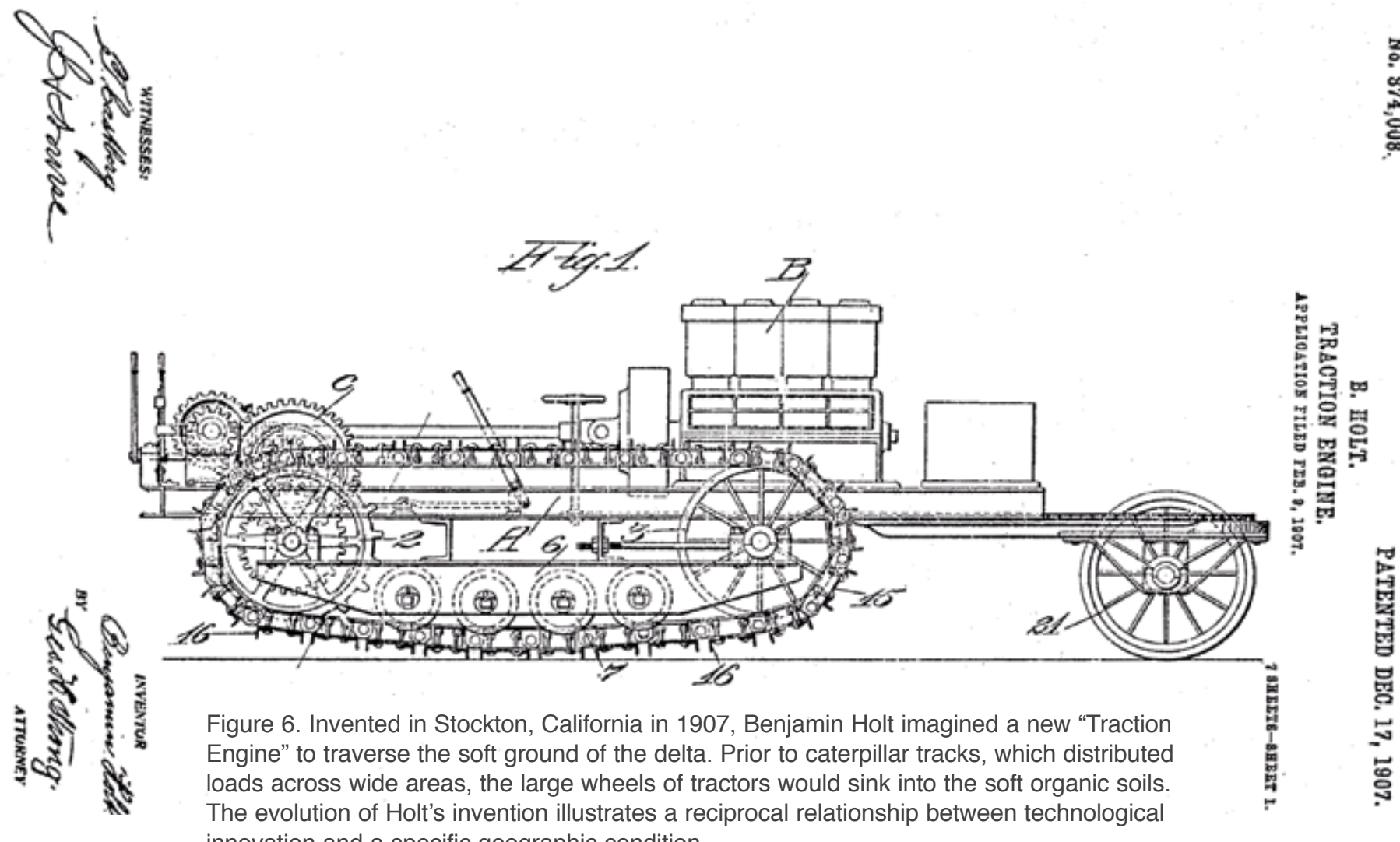

delta, elaborate irrigation systems were being invented to choreograph the extraction and surface movement of irrigation water (Fig. 7). This effort was far reaching and extended beyond the delta region. Alexander Parker, for example, invented a device to control the exchange of ocean and bay waters that would have changed the delta's salinity by restricting tidal exchange at the Golden Gate allowing for more fresh water to ready the San Pablo, Suisun, and San Francisco Bays (Fig. 8). And Daniel Spangler, a resident of Tulare, California in the Central Valley, invented a "Submarine Wall" in 1885 to facilitate the passive dredging of bay bottoms such as 


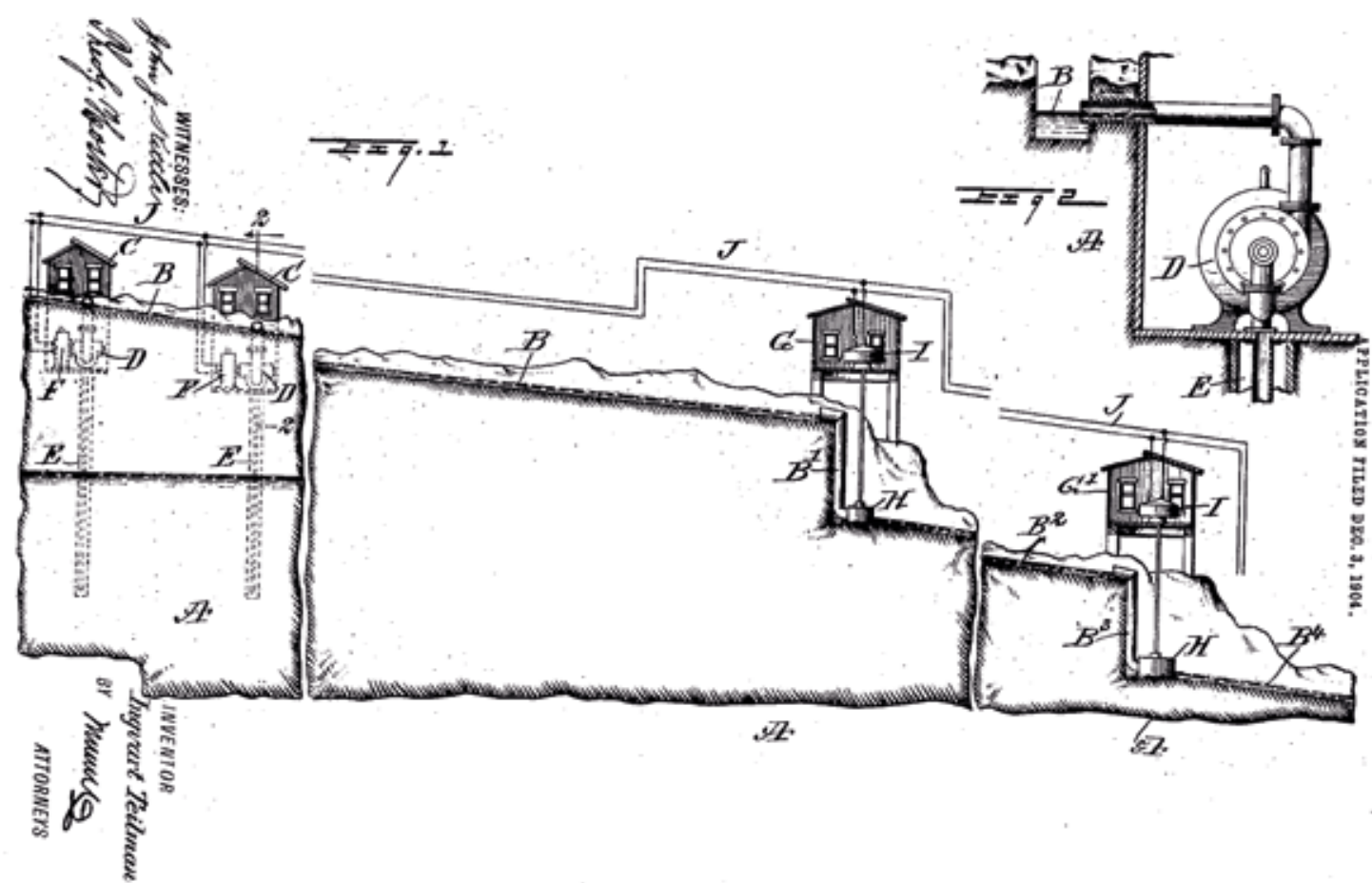

Figure 7. Invented in Fresno, California (1906), Ingvart Teilman's "Method and Means for Procuring Water for Irrigation and other Purposes" imagines a topographical water systems that integrates inclined waterways with water-powered pumps to continuously extract groundwater and distribute it throughout the area. The process is gravity fed, allowing for the irrigation of agricultural land to be combined with a process of groundwater extraction.

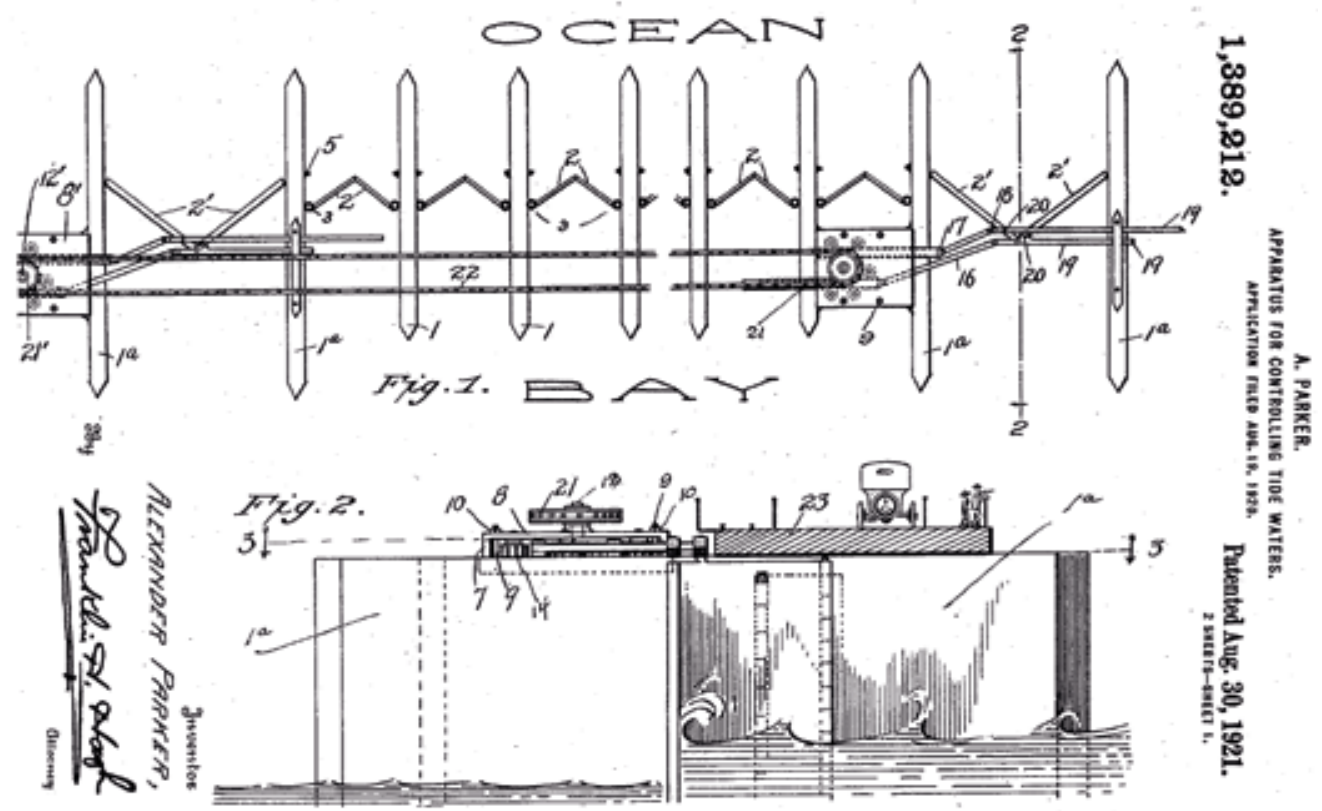

Figure 8. Invented in Etna Mills, California 1921 by Alexander Parker, the patent for "Apparatus for Controlling Tide Waters" imagines an system for controlling tides at the entrances of bays where salt and freshwater are interchanged. The device is comprised of a series of parallel piers and gates hinged at corresponding points. The gates are inclined to each other, opening out from the bay and automatically closing with the incoming tide. The invention would have vast territorial consequences, essentially turning the San Francisco Bay into a freshwater lake. The apparatus is also best understood in relation to the Reber Plan of the 1940s. 
Figure 9. Invented in Hanford, California (1885), Daniel Spangler's patent for a "Submarine Wall" imagines a subsurface louvered wall that focuses tidal power to self-dredge navigable channels. The system harnesses the hydraulic power of tidal exchange to passively dredge shallow bay bottoms such as those found in the San Francisco and Galveston Bay. The patent is also significant for its use of cartographic drawings that suggest a regional, or territorial, scale for technological innovation.
D. SPANGLER.
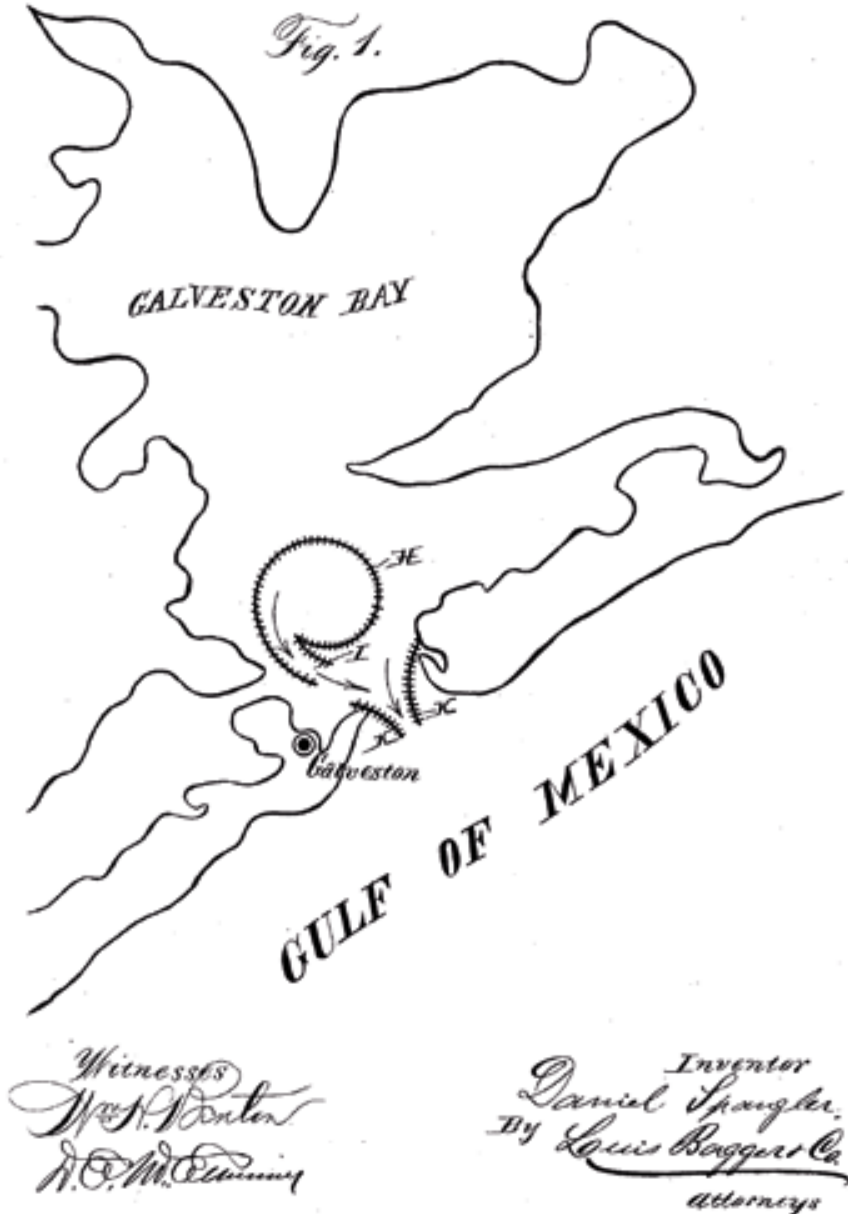

those found in Galveston and San Francisco ${ }^{17}$ (Fig. 9).In essence, inventors from the California Delta region successfully posited nature as the subject of technological innovation, and through this process, the US Patent Office became a legal and institutional mechanism for the diffusion of radical environmental thinking (Fig. 10).

The California Delta and its adjacent fertile valleys was a rich muse for the environmental imagination, becoming a distinct geography of innovation with farsighted technology inspired by this frontier landscape. The reciprocal relationship between technology and environment is perhaps most evident in the works of Frank V. Wright and Newton Sewell, who developed radical new technologies that entirely reimagined infrastructure in the delta. Frank V. Wright of Alameda, California, and descendant of the owners of Wright's Tract, developed a series of levee machines and construction methods during his lifetime. His swansong, a "Method for concurrently maintaining and cultivating levees," discloses a process of levee formation integrated with agriculture in which land is created and 
Figure 10. Examples of environmental innovation span diverse sectors of technology and geographies.

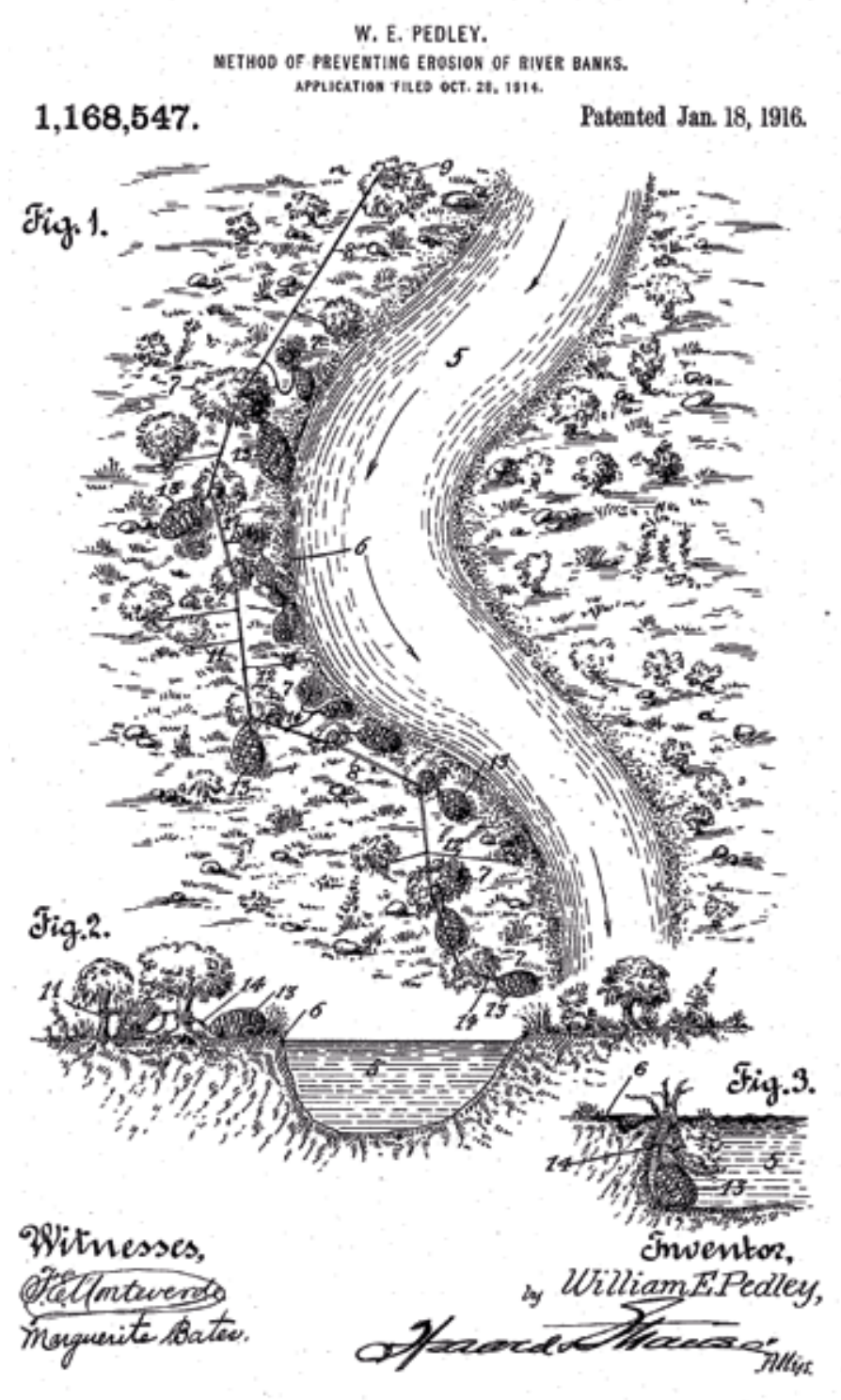

(a)

Figure 10a. Invented in Riverside,

California, 1916, William Pedley's imagines a "Method of Preventing Erosion of River Banks" establishes an anticipatory series of control devices along the banks of rivers. The system allows for the migration of river channels within set boundary that becomes activated once reaching a predetermined point (a).
\#. NBWEOUSE. TIDE-POW BR.

No. 189,643 .

Patented April 17, 1877. Fig.t.

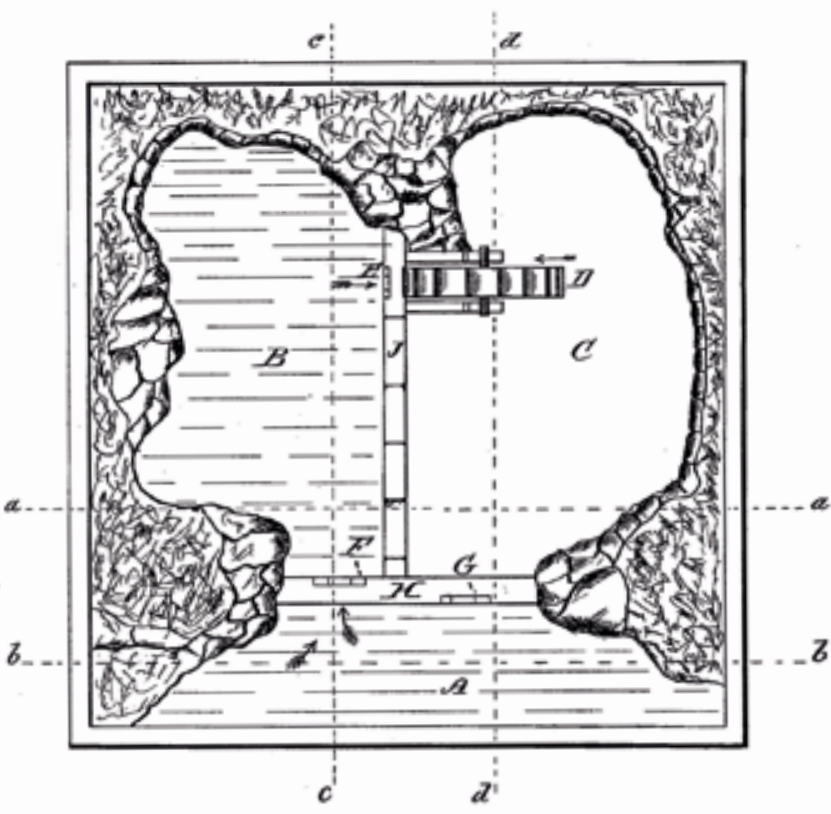

Figir.

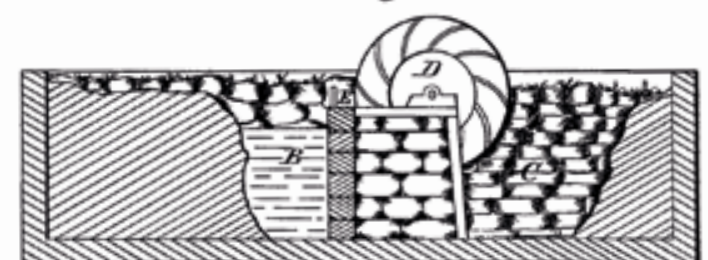

Wohne At, Redutine.

Heneg Sewhouse.

Qte chwhonse.

(b)

Figure 10b. Invented in Oakland, California, 1877 by Henry Newhouse, this patent for "Tide Power" imagines an embayment that orchestrates the movement of tide-waters to generate power. The ebb and flow of the tide powers a water wheel, converting water movement into energy (b). 
crops irrigated through the application of sediment slurries (Fig. 11).

The polyfunctional levee imagined by Wright provides a rich vision of an alternate future for leveed lands in the delta, but may have also helped reduce subsidence through the incremental addition of new sediment and organic materials. Similarly, Newton Sewell of Yuba, California, invented a system to use the excess sediment created by goldrush mining activity to build levees. Mr. Sewell's patent for a "Method of relieving river channels of sediment" (Fig. 12) utilizes a series of small subsurface dams and diversion channels to settle out sediments and reclaim new land. These inventions are noteworthy not only for their vanguard reinterpretation of landscape infrastructure, but also for their relationship to the contingencies of the California Delta itself.

The emergence of new technologies along the frontier was integral to
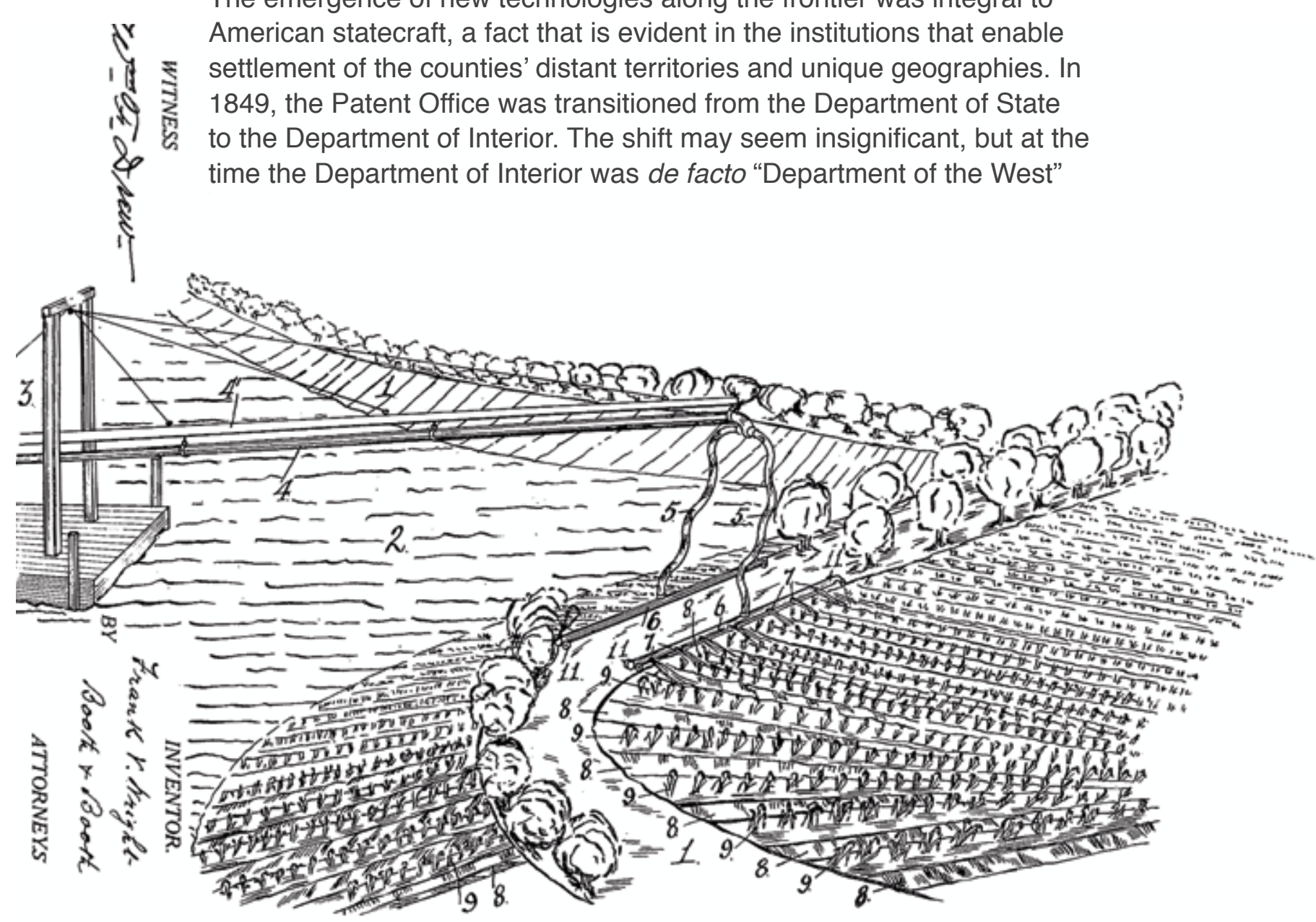

Figure 11. Invented in Alameda, California in 1918 by Frank V. Wrights, this patent created a "Method of Concurrently Maintaining and Cultivating Levees" by imagining a system of flood protection integrated with agriculture. The process of growing crops and levees simultaneously is achieved by irrigating with sediment heavy water from adjacent waterways. The Wright family were early settlers of the delta, and were granted a tract of land as part of the Swamplands Act. Frank Wright patented his first levee protection system in 1904, and in consecutive years patented a dredge boat, levee construction method, and ultimately a system to integrate agriculture and levee building into a polyfunctional system. 
since it contained the Bureau of Census, Indian Affairs, Patent Office, and General Land Office, in addition to managing western territories. Some scholars have even argued that this combination of duties would have laid the groundwork for an early "Department of the Environment" to emerge in the mid nineteenth century. ${ }^{18}$ In hindsight, it becomes evident that commodification and settlement of the western United States was paralleled by the commodification of the techniques, technologies, and devices that empowered inventors to transform the environment and also promote a democratic and entrepreneurial future along the frontier.

\section{POSSIBLE FUTURES OF THE DELTA: A BOTTOM-UP AND ENTREPRENEURIAL APPROACH}

While the patent itself was typically a bottom-up act of design, its aggregative effect provided a unique model for territorializing the frontier that was incited by the individual itself as an inalienable right protected by the U.S. Constitution. In fact, it was customary for the patent descriptions to commence with the inventor announcing their name and place of inhabitation-revealing both the empowered individual and the imagination

Figure 12. Invented in Marysville, California, 1880, Newton Sewell's patent for a "Method of Relieving River Channels of Sediment" envisions a sediment management system that captures material from hydraulic gold mining to form levees in the Central Valley. Sediment from the Sierra Nevadas choked delta channels and altered the bathymetry of Bay bottoms. Mr. Sewell's patent discloses a process of levee creation that captures excess sediment and directs the material to dewatering enclosures. The process utilizes low-crested check dams, or weirs, to divert sediment-laden bedload into enclosures of varied height and width. When envisioned serially, a vast self-building and renewing levee system can be imagined in the delta.
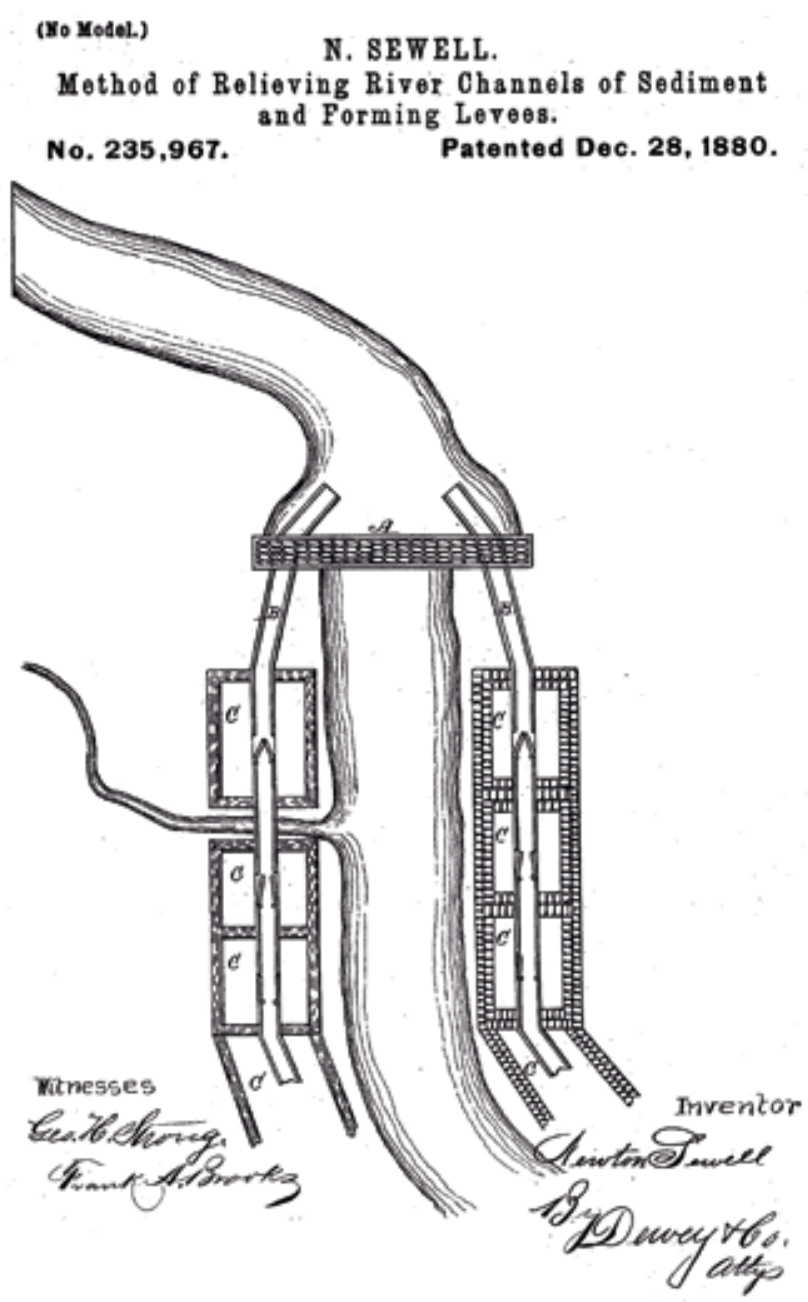
incited by their specific geography. This method for territorialization stands in distinction to ensuing water projects such as the Colorado River Project (1913), Central Valley Project (1933), and State Water Project (1960-Present) that deployed top-down engineering to essentially convert California into an integrated water machine that often ignored the local specificities of geography and culture. Like all massive infrastructural projects, these required large institutions and agencies, capital investment, and time. The Swamp Lands Act, and the work that proceeded from it, offer a distinct alternative to the better-known mega projects of the last century. Might a landscape strategy be developed that learns from this process?

Technological innovations tend to emerge along the frontier. Early environmental frontiers necessitated that nature be reimagined as a commodity and resource. The impetus for the technologies developed along the frontier emerged from an accepted understanding of nature being a distinct object from society, and only through this separation from a "society in nature" to a "society and nature," could it be rendered a commodity. ${ }^{19}$ The ramifications of this worldview, which has effectively put nature to work, are being witnessed through increasing predictions of sea level rise, earthquakes, and desertification in the Delta region. These forecasts have sparked a plethora of future scenarios for the Delta that are as diverse as its contingencies and constituencies-massive subsidence, levee failure, ecological collapse, drought, receding groundwater, new state water plans, and divestment in traditional forms of statecraft. What is shared and exposed in these divergent scenarios is the futility in attempting to control nature and the difficulty of coordinated megaprojects and infrastructure in the messy democracy of twenty-first century America. Despite this, current plans such as the California WaterFix continue to consider nature as a separate entity to be controlled, and advance a top-down future for California's water.

The project of rewilding and restoring the California Delta positions it as a new type of frontier whose re-naturalization requires similar experiments of the imagination and engineering as is observed in the Swamp Lands Act more than a century and a half ago. The deployment of new technologies to re-wild this new frontier could serve as a model for other degraded, extracted, and used anthropogenic drosscapes. ${ }^{20}$ And while this at first seems like a technical issue to be resolved by engineering, we posit that this is foremost a cultural project that requires a revived environmental imagination that considers "society in nature" coupled with a parallel process of sociotechnical innovation. This would privilege new technologies that operate akin to nature-negotiating complex systems through design innovation and socio-ecological governance. ${ }^{21}$ Of course there are ongoing efforts to renaturalize parts of the Delta, build habitat, and reverse subsidence, but this vision is still piecemeal and insufficient. Instead, let's employ the environmental imagination that proactively acknowledges the feedback between the territorial transformation, novel ecology, and technology. 
Looking at deltas around the world we can see the impacts of top-down mega projects in sites from the Netherlands to the Mekong, but what about bottom-up and entrepreneurial approaches to deltaic landscapes? Arguably it is alive and well, yet often remains outside the purview of designers, engineers, and policy makers. Instances of the bottom-up approach to resilience have emerged in southern Louisiana where the delta of the Mississippi is rapidly sinking into the Gulf of Mexico. In this disappearing landscape, entrepreneurs and inventors such as Webster Pierce and Mark Gagliano (Figs. 13,14) are prototyping solutions to coastal land loss and oyster reef restoration, while the state attempts to fund a multibillion-dollar coastal masterplan. ${ }^{22,23,24}$ Similarly, agencies such as the National Resource Conservation Service are working to engage inventors and technologist to advance sustainability through programs like the Conservation Innovation Grants that promote development of novel technologies. ${ }^{25}$ And the Nature Conservancy is developing programs that foreground the restoration economy, including investments in novel technologies for oyster reef

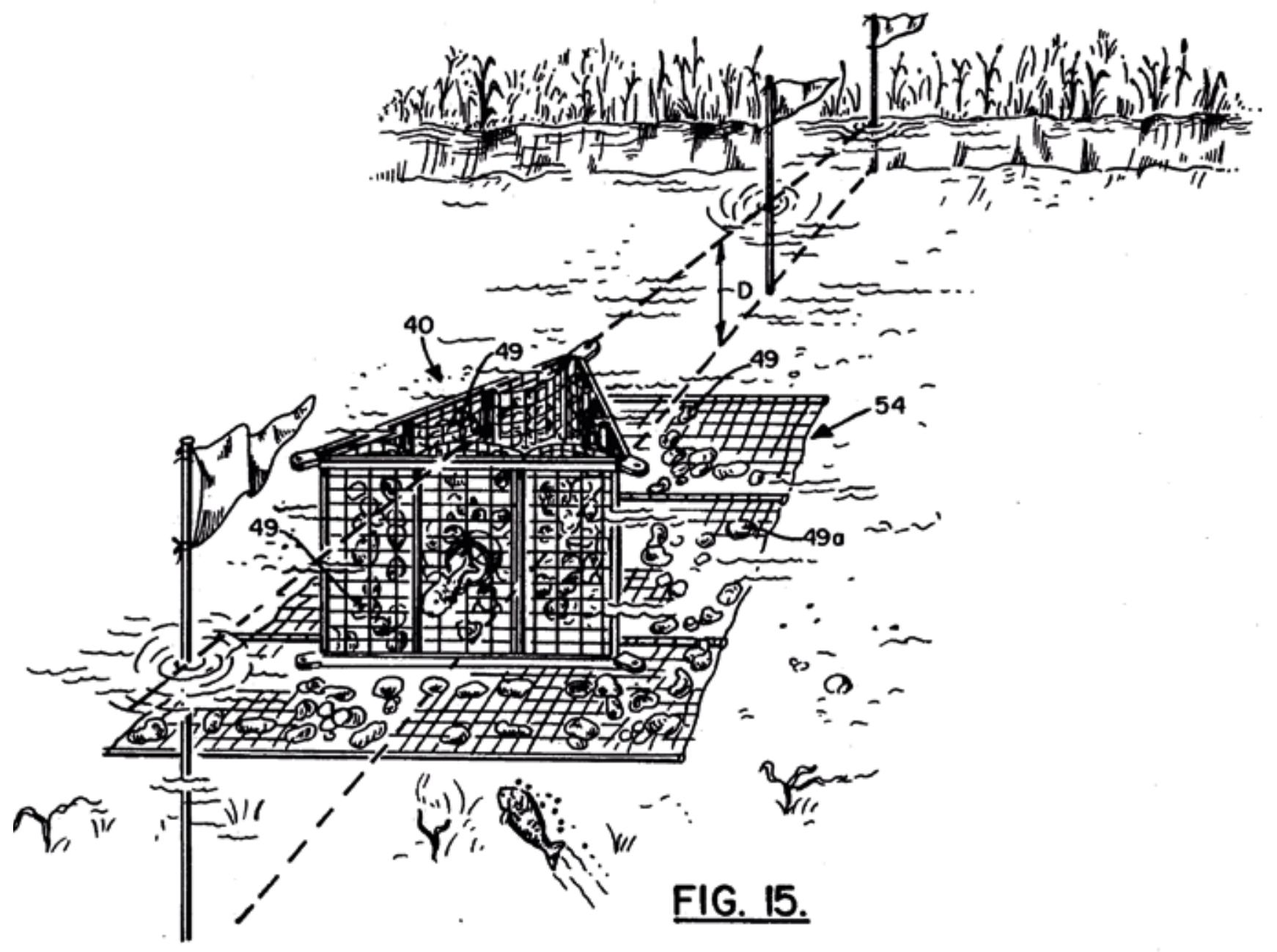

Figure 13. Invented by Mark and Sherwood Gagliano in Southern Louisiana. "Method and apparatus for growing oyster reef," US Patent US07908469. 
restoration in partnership with companies such as Wayfarer Environmental Technologies. ${ }^{26}$ These emergent examples reveal a distributed approach to re-wilding and the creation of landscape infrastructure, enabling space for citizens to innovate while acknowledging the messy realities of a participatory democracy.

\section{(19) United States}
(12) Patent Application Publication Pierce, JR.
(10) Pub. No.: US 2014/0314484 A1
(43) Pub. Date:
Oct. 23, 2014

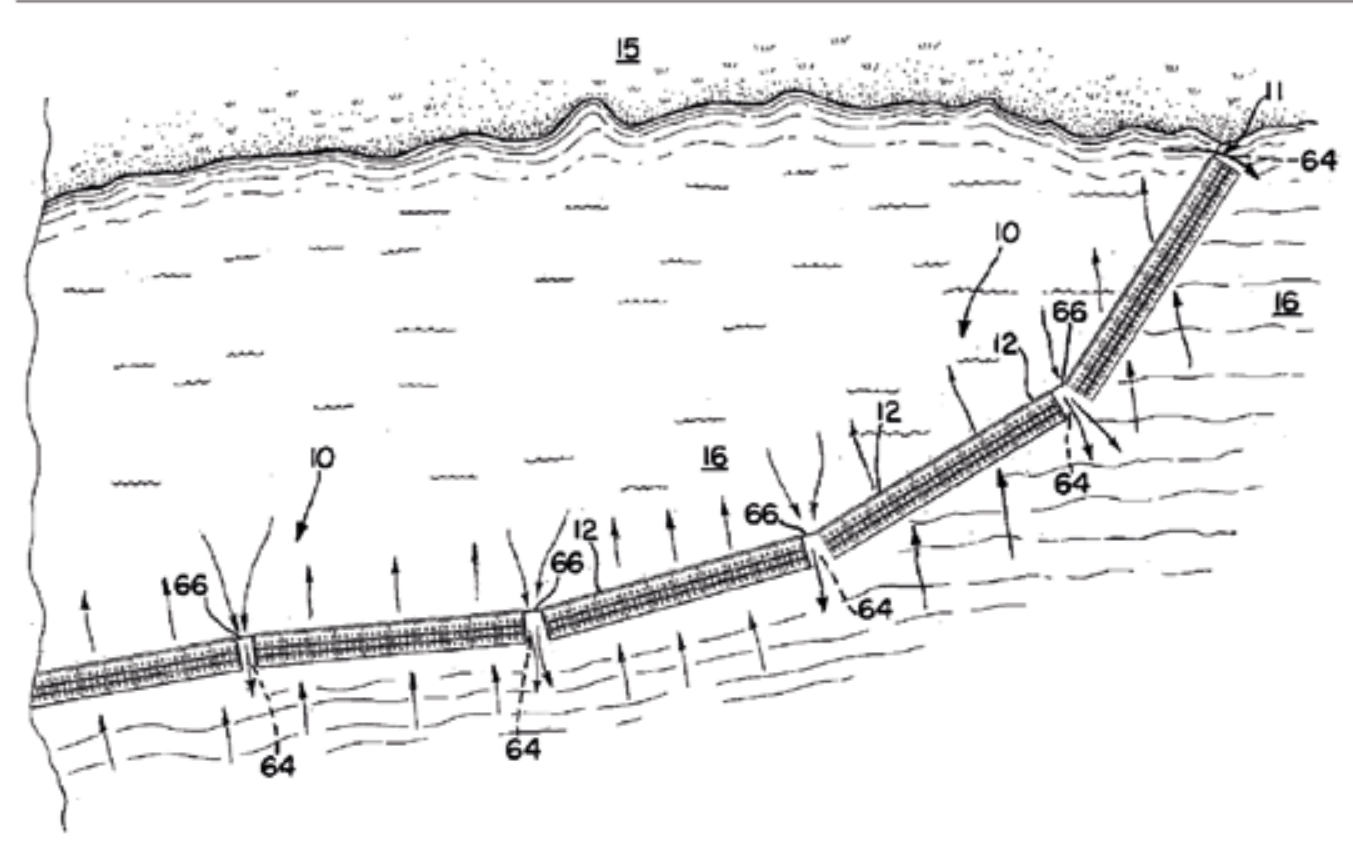

Figure 14. Invented by Webster Pierce Jr. in Southern Louisiana. "Wave suppressor and sediment collection system for use in shallow and deeper water environments," US Patent Application 20140314484A1.

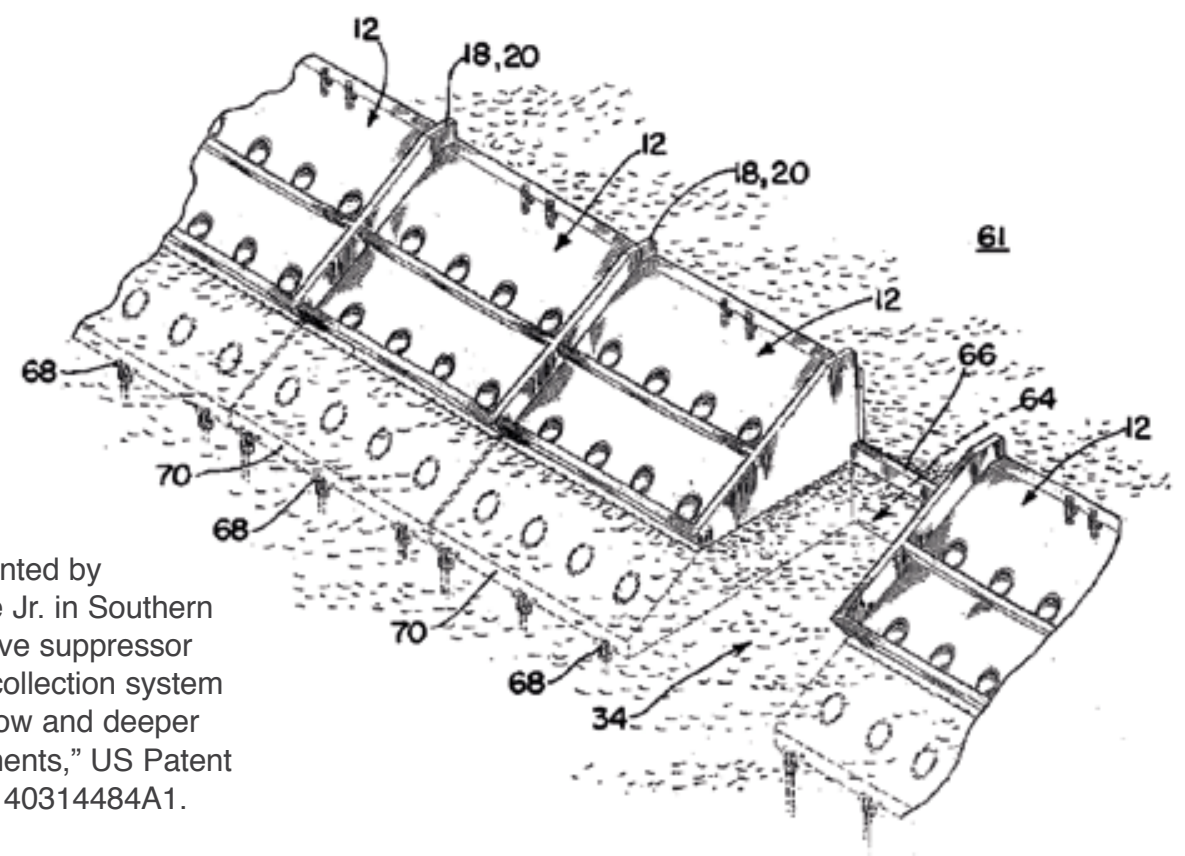




\section{EXPERIMENTAL PEDAGOGIES AND THE ENVIRONMENTAL IMAGINATION}

In the last decade, we have witnessed an expansion of the fields of architecture and landscape architecture to broadly shift the focus of discourse from discrete sites and buildings to larger environmental systems and territories. Of course, while increased design agency may exist at this larger scale - that more overtly interfaces with politics, economics, and environment - it must also confront complex negotiations among diverse stakeholders, policies, timescales, and often clients that do not (currently) exist. This complexity has largely advanced a disciplinary wide mapping project that has been instrumental in depicting new geographies, but rarely provides a framework for designers to act within it. Arguably, it has also rendered a generation of students paralyzed to design within this complexity, and often leads to abstract, utopian, or highly speculative design proposals that fall into the trappings of historical megaprojects. Perhaps beginning with the tangible details, specific technologies, and an understanding of discrete systems, may offer a methodology to understand larger territorial impacts just as they did in the early American history of the California Delta?

In the summer of 2016, we (the authors) lead a workshop as part of DredgeFest California that centered on sedimentation and earthworks in the California Delta. ${ }^{27}$ During the weeklong workshop, participants and workshop leaders were asked by the DredgeFest organizers (Dredge Research Collaborative) to act thoughtfully and quickly to develop responses to a series of scenarios that covered the range of possible futures in the delta. Our team of designers (including Mario Accordino, Alexandra Zahn, Michael Biros and Paul Cooper) was given the challenge of visualizing scenarios for the future earthworks of the delta that ranged from state funded megaprojects to neglected levees and further subsidence. ${ }^{28}$ Instead of trying to unpack the full complexity of the California's Delta in such a short duration, we focused on the design of discrete technologies and simulated their territorial effects as bottom-up acts of design speculation. This allowed us to begin iterative design experiments right away using a heuristic model based on patent innovations, and, as the workshop progressed, it enabled us to understand the relationship between a discrete technology and the broader region.

After a short initial exercise exploring existing technologies from the patent archive and extrapolating their territorial impact, ${ }^{29}$ four new technologies were "invented" with the ambition of steering their transcalar effect. Graphic standards were borrowed from patent documents, and included details of how the system operated at the scale of the detail, to the scale of the region, and addressed issues ranging from subsidence and accretion of sediment, to aquifer recharge and levee reinforcement. For example, the Banking system, created by Alexandra Zahn, addressed the levees of the delta. Her invention supports existing levees, and in time, replaces them 
with an embankment behind the existing levee wall. The process of creating the double levee also recharges aquifers through a process of draining waters in the interior of the leveed polder landscape and using hydrological pressure differential is created to promote the accretion of sediment through silt fencing. Similarly, the Regional Reinforcement system, created by Michael Biros, addressed the issue of sea level rise and land subsidence in low-lying areas. The object of the invention was to provide a method to convey and disperse sediment through easily deployable sluices that direct water into permeable seepage and dewatering structures. And, the Landform Zipper system, invented by Paul Cooper, aimed to capture sediment in serially arrayed wooden tetrahedron structures anchored in channels of the delta with bioengineered plashing.

The outcomes of the workshop are succinctly articulated in images of the Tule Tech system designed by Mario Accordino (Fig. 15). Subsidence is a major issue in the delta, resulting form years of till farming, oxidation of organic soils, and extraction of ground water. The Tule-Tech system aims to reverse subsidence by creating landscape building block comprised of tule as a substrate and structure for raising land. The invention choreographs material economies around the growth of tule throughout the California Delta, and the creation of a "tule-bales" from this biomass. Tule-bales become the basic territorial building block, and can be assembled in different configurations to elevate the ground plane and perform vital functions for restoration. The production of tule as a building unit allows for farmers to grow the biomass in distant areas of the delta with adequate water, and aggregate the bales in areas of economic, environmental, and cultural production. Deployed at landscape scale, the tule-bale could play a significant role in reversing land subsidence by providing a basic building block to construct a new ground. Overtime, the decomposed tule biomass would also provide a substrate for agricultural production and ecological restoration.

Moving away from a top-down deductive process, we were able to focus quickly on a series of design experiments rooted in a bottom-up and inductive approach that aggregated into scenarios for the California Delta. By developing a specific technology and understanding how it would re-territorialize or re-wild the landscape, it allowed workshop participants to quickly understand the implications of their design proposals, moving back and forth between technological invention, and region ramifications, ultimately facilitated design experimentation at the scale of the territory and at the detailed scale of a specific technology developed by the designer. The difference between these experiments and those of the grand megaproject or speculative mapping is the feedback between the micro and macro. Territorial effects could be explicitly directed and choreographed by acknowledging the transcalar relationship between various components. In essence, we posited that singular devices and technologies could 


\section{TULE-TECH}

(19) United States

(12) Patent Application Publication (10) Pub. No.: US 2016/0185724 A1 The Bureau of Territorial Technologies

(43) Pub. Date: June 17, 2016

(54) TITLE: METHOD FOR

APPROPRIATING

SCHOENOPLECTUS ACUTUS FOR

AGRICULTURAL ARMATURE, DESALINATION AND LAND

(75) ACCRETION

(73) Inventors: Mario Accordino

Assignee: Bureau of Territorial

(22) Appl. No.: Technology

(23) Filed:

$12 / 495,5823$

June 17,2016
(57)

\section{ABSTRACT}

Be it known that I, Mario Accordino, an agent of the Bureau of Environmental and Territorial Technologies, and resident of Oakland California, have invented a certain new and useful method for appropriating harvested Schoenoplectus acutus, tule, for armature in agricultural production, water desalination and land accretion.

The plot of land upon which the system will be deployed is flooded with saline water to a depth of 12 inches. Concurrently, a separate island (Fig.4.A) harvests and bales tule (Fig.1), which is then assembled according the user's desired application and amount of available tule. (Fig. 3) Organic material then serves as infill for agricultural planting soil (Fig. 2B). Finally the system is enclosed in a plastic sheeting, which colleets water vapor from the saline water beneath and drips freshwater from the plastic sheet to the crops below (Fig. 2D). As the material of the tule decomposes, the land beneath collects the plant detritus and gains elevation over a process of years. (Fig. 4)

US 20120110942A1

05.10 .2012

US 4312601

01.26 .1982

US 3680296

08.01 .1972 act as tule farming factories, producing material for more deeply subsided islands. As potential freshwater availability dwindles, the majority of Delta islands will transition from producing tule to using tule in agricultural service. (Fig 5, 7,8)
At the onset of production, upland Delta islands will

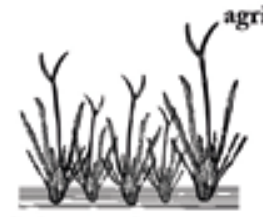

Schoenoplectus acutus

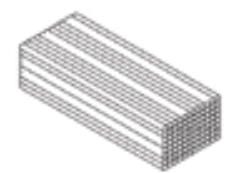

BAI.E

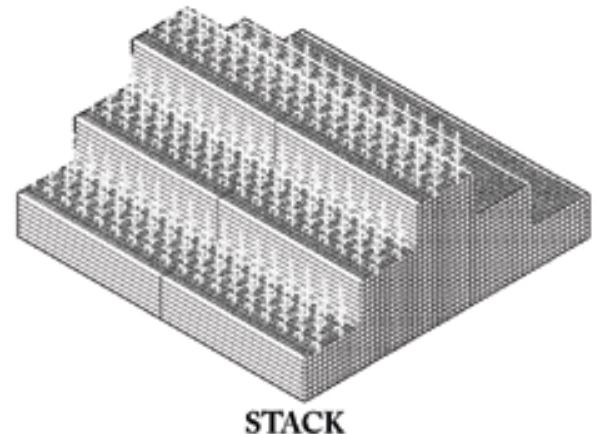

Fig 1 .

Figure 15a. TULE-TECH: A Method for building up land, agriculture, and fresh water production. 


\section{(19) United States \\ (12) Patent Application Publication The Bureau of Territorial Technologies}

(10) Pub. No.: US 2016/0185724 A1

(43) Pub. Date: June 17, 2016

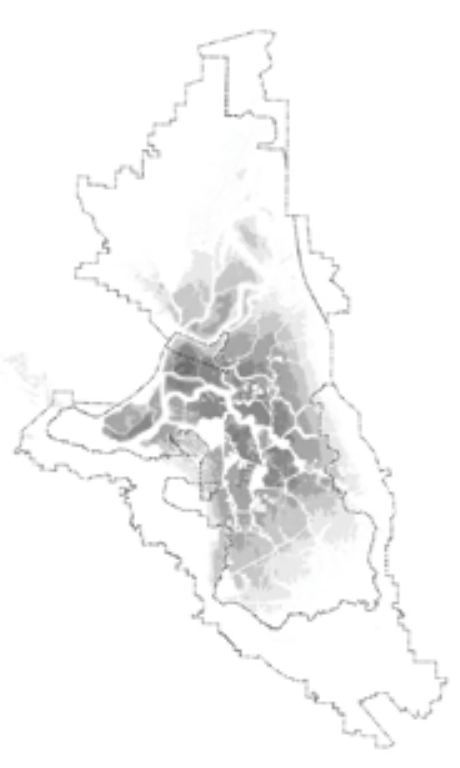

CURRENT SUBSIDENCE

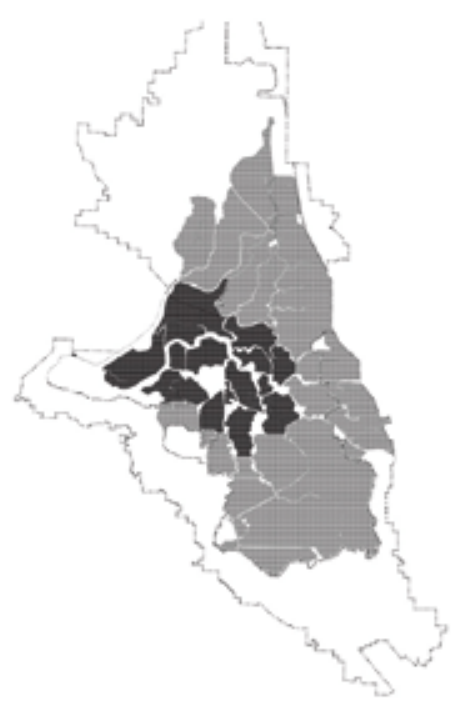

15 YEAR DROUGHT PRODUCTION ISLANDS: 25 CONSUMPTION ISLANDS: 20

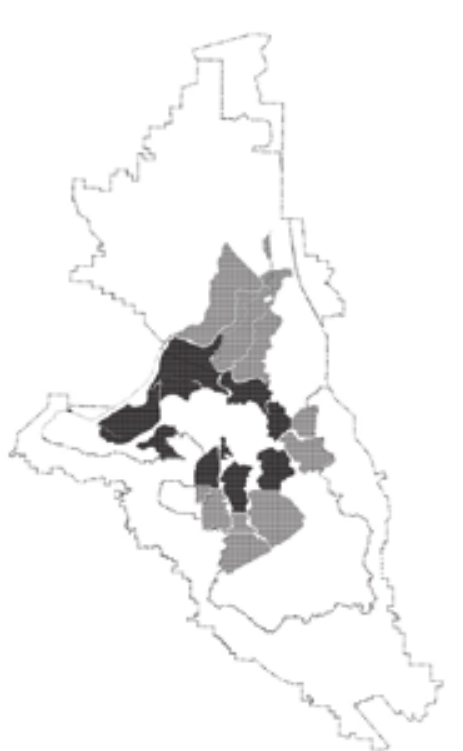

2 YEAR DROUGHT PRODUCTION ISLANDS: 15 CONSUMPTION ISLANDS: 10

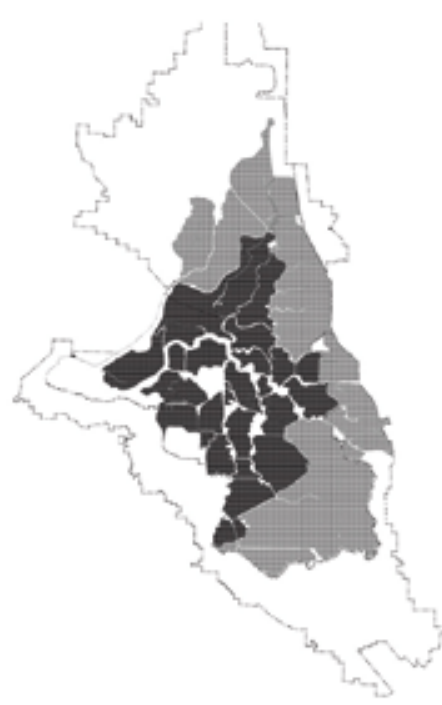

25 YEAR DROUGHT

PRODUCTION ISLANDS: 15

CONSUMPTION ISLANDS: 30 


\section{(19) United States}

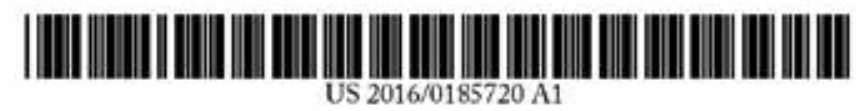
(12) Patent Application Publication
The Bureau of Territorial Technologies
(10) Pub. No.: US 2016/0185724A1 (43) Pub. Date: June 17, 2016

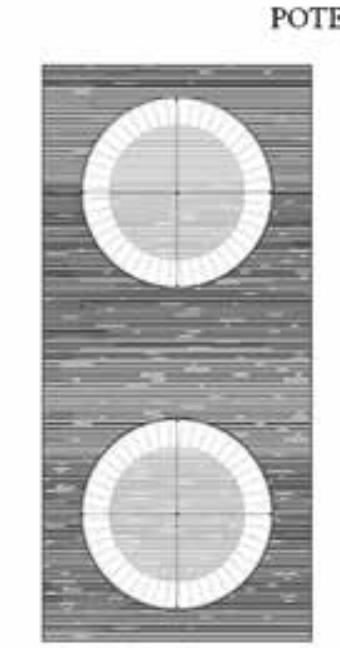

No. 1

1,800 BALES / 100 ACRE

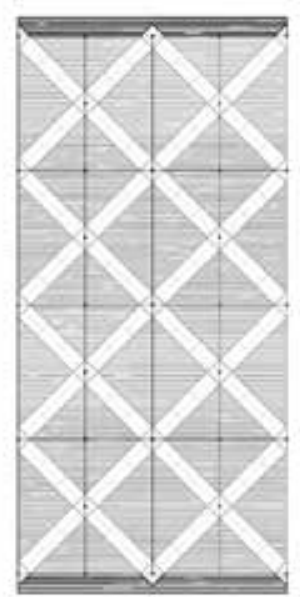

No. 2

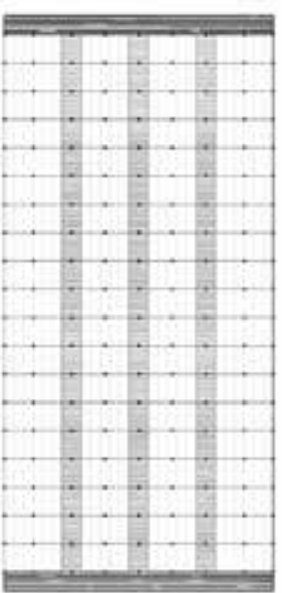

No, 3

4,400 BALES / 100 ACRE 6,400 BALES $/ 100$ ACRE

Fig 3 .

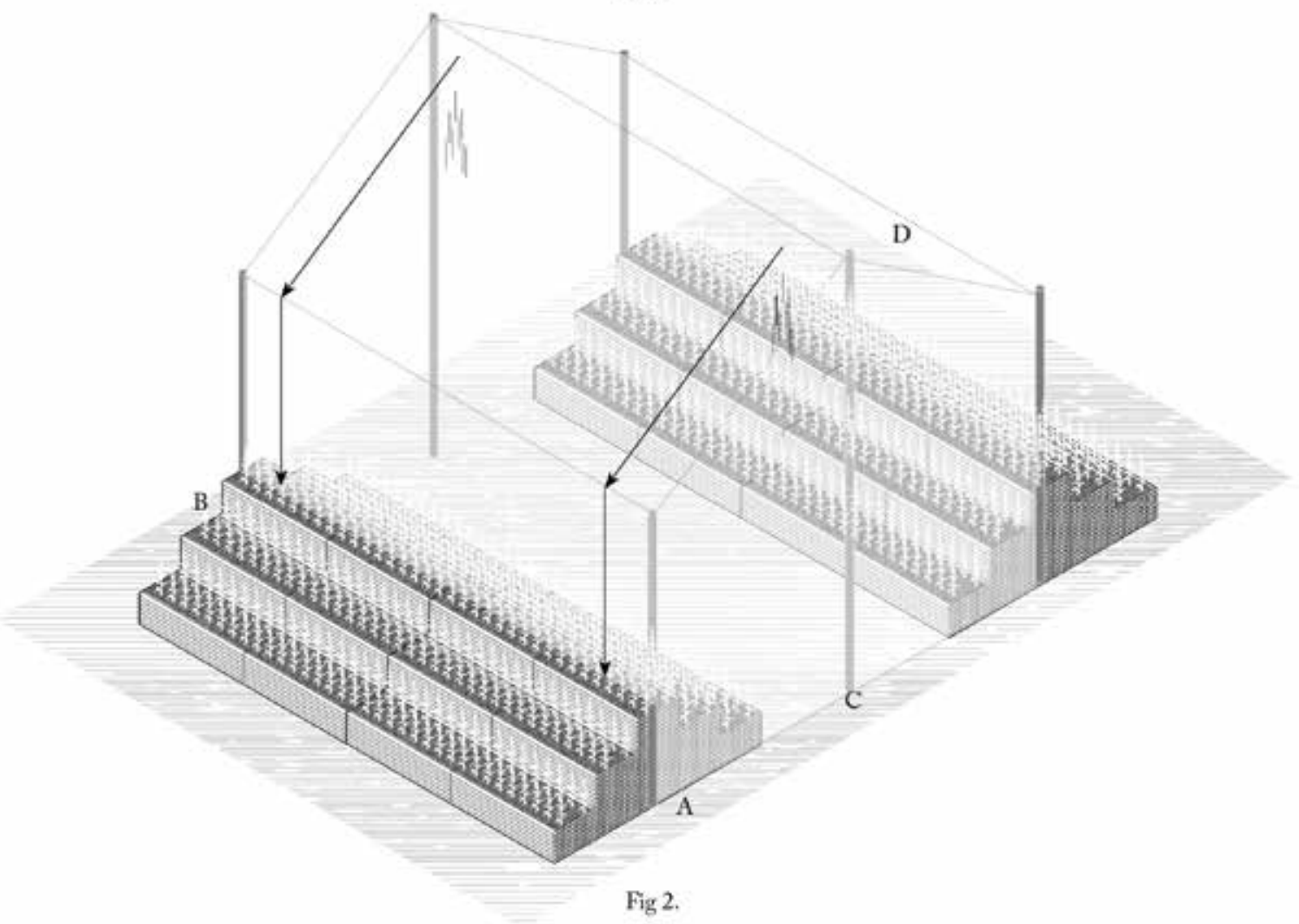

Figure 15c. TULE-TECH. 
(19) United States

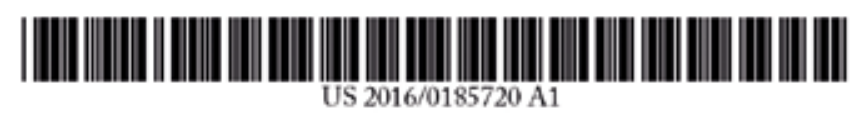

(12) Patent Application Publication (10) Pub. No.: US 2016/0185724 A1

The Bureau of Territorial Technologies

(43) Pub. Date:

June 17,2016

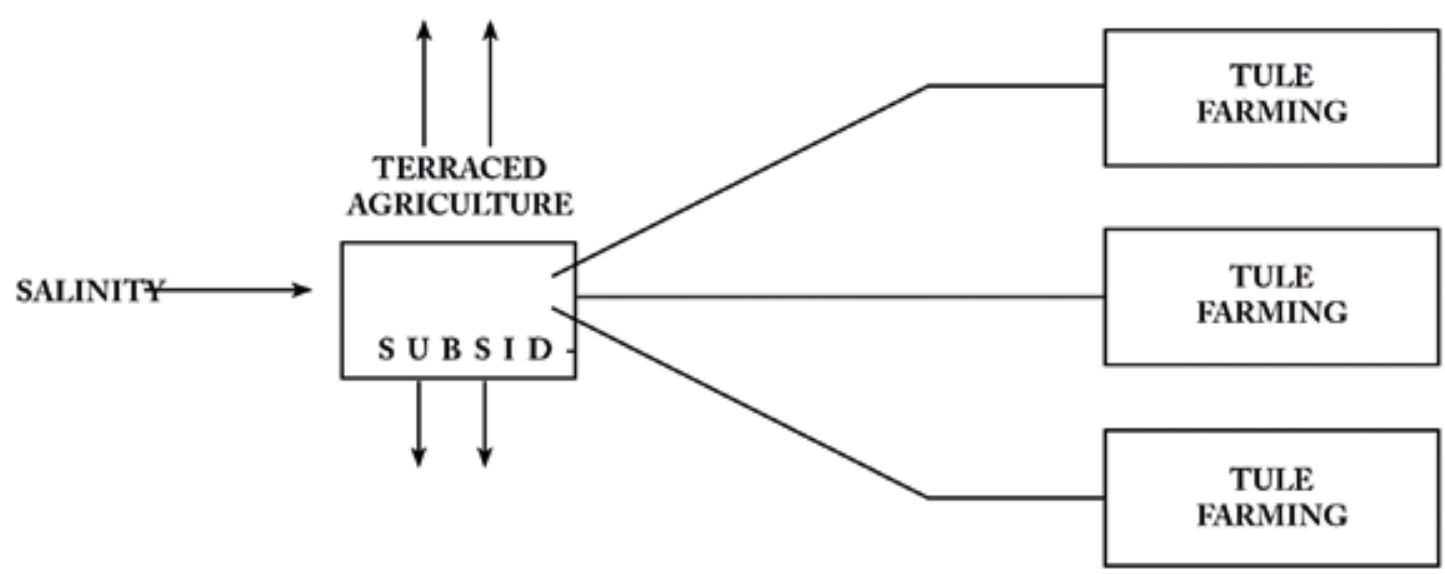

Fig 6.

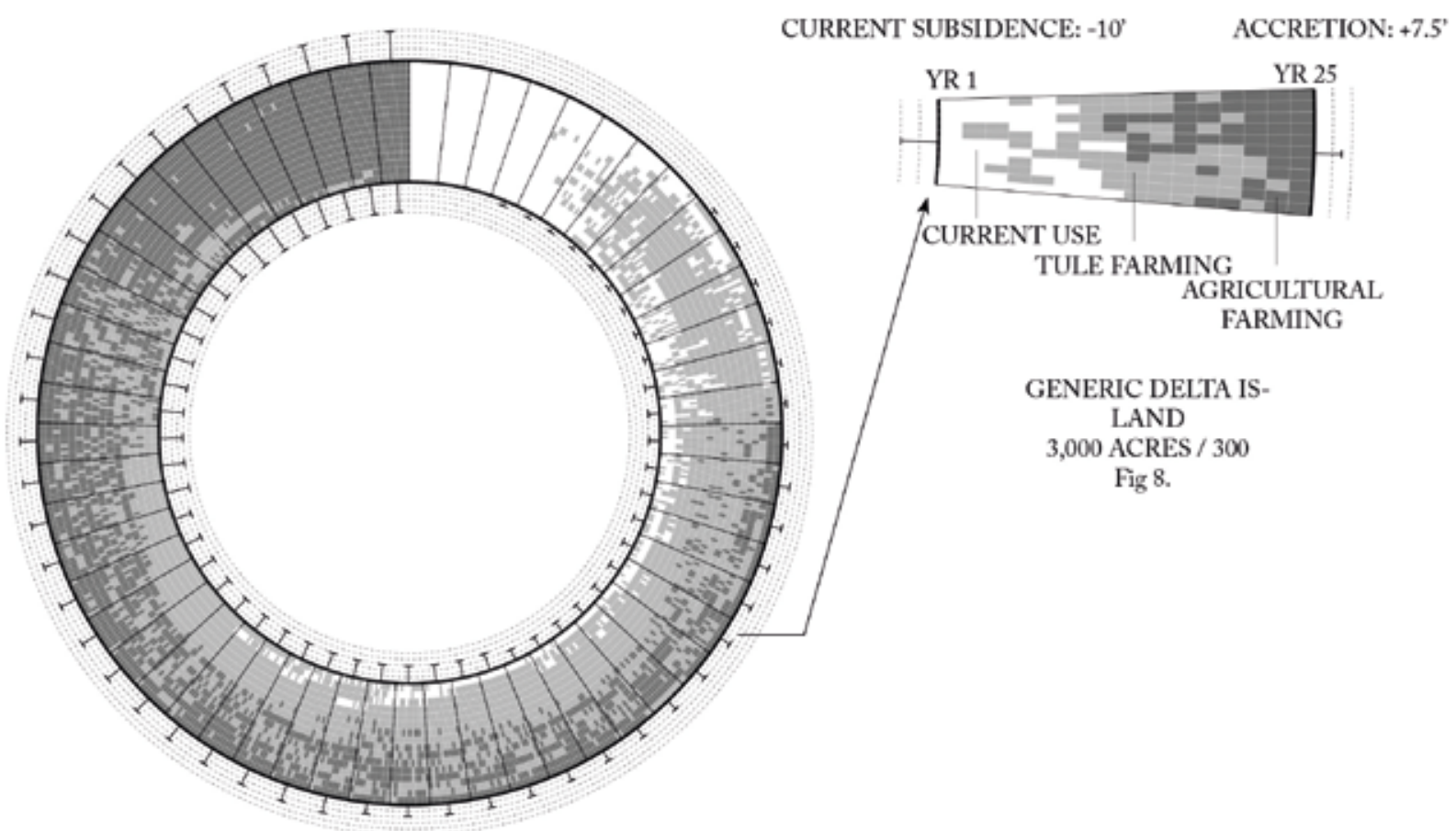

Fig 7.

Figure 15d. TULE-TECH. 


\section{(19) United States}

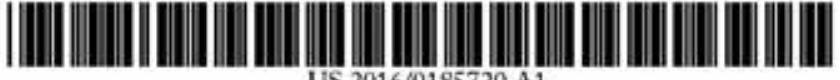

(12) Patent Application Publication (10) Pub. No.: US 2016/0185724A1

The Bureau of Territorial Technologies

(43) Pub. Date: June 17, 2016

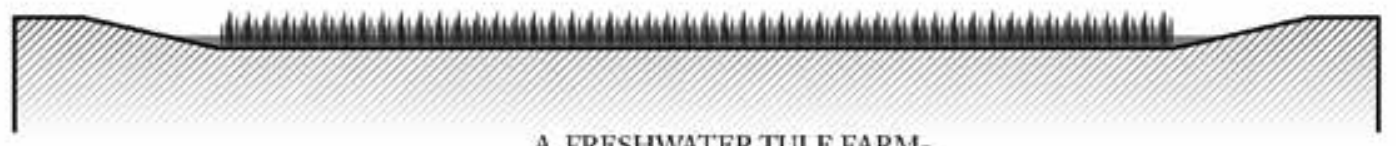

A. FRESHWATER TULE FARM-

ING

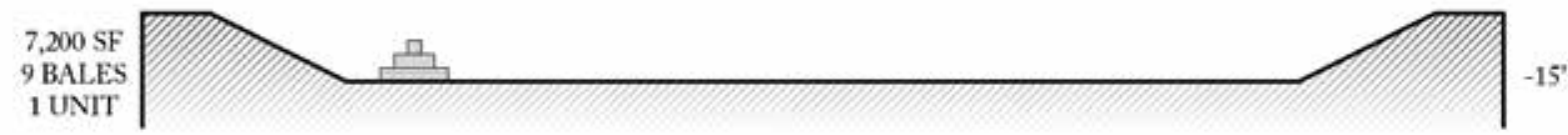

B. YEAR 0

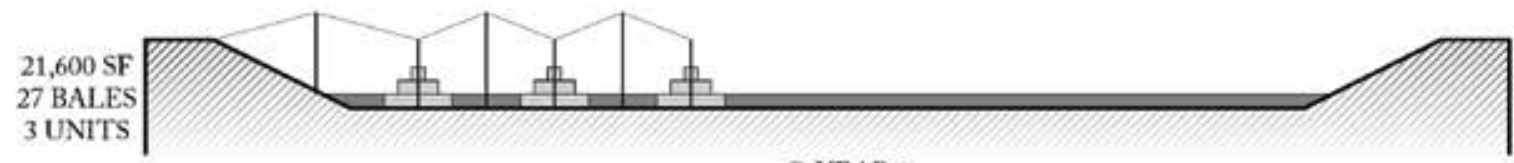

C. YEAR 1

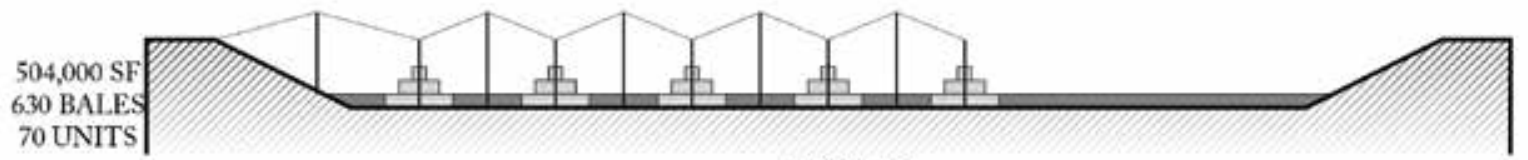

D. YEAR 2

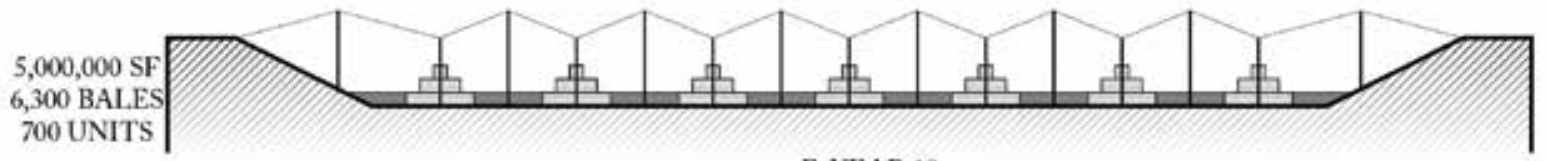

E. YEAR 10

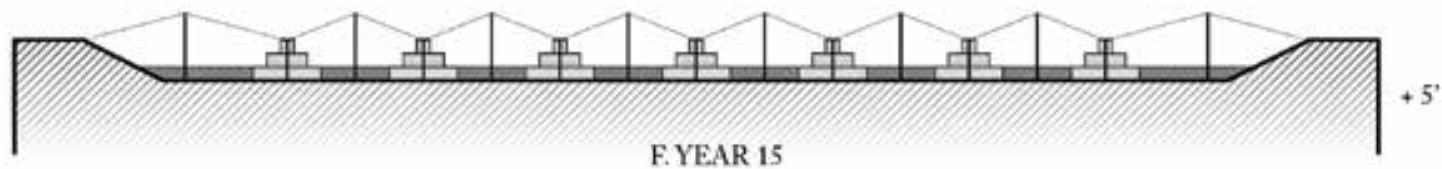

F. YEAR 15

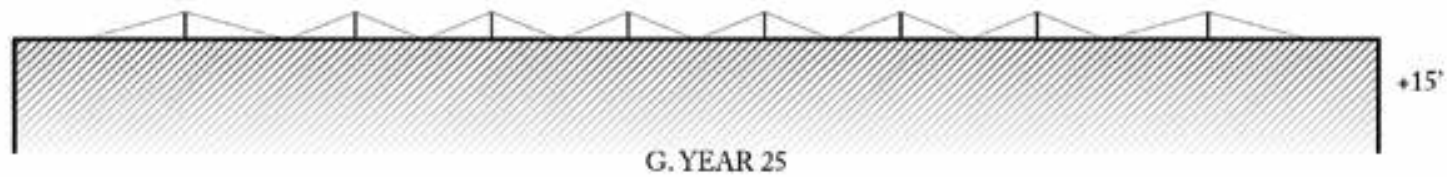

Fig 4.

Figure 15e. TULE-TECH. 
effectively reconfigure a large-scale territory, and if so then designs agency might be most expeditious at the small scale, yet aggregate to impact much larger systems over time. When considering this through the lens of professional practice and real world projects, it is interesting to imagine that landscape architects, and architects, might invent machines, processes, and technologies that increase disciplinary agency at the territorial scale, without the need for conventional clients or government backed projects.

The solutions that emerged from this approach intended to contextualize the trans-scalar nature of technological landscape instruments. While these innovations at first seem to be solely "problem-solving," they offer a discernable mechanism to precisely engage a conversation about how these would be funded, built, and maintained as well as what socio-cultural ramifications and opportunities would emerge through their deployment. This not only reaffirms the power of iterative design thinking, it suggests a process that engages diverse stakeholders in tangible scales and ways to intervene in the landscape through a soft-system distributed approach. Perhaps most importantly, this technique might be able to bypass our current cultural paralysis around climate change issues, which are too large, too abstract, and not immediate enough - in terms of perceptual effects to the daily lifestyle of most Americans - to incite the forms of action that are urgently required.

\section{CONCLUSION}

The California Delta provides us with a fascinating case study on the transformation of wilderness to territory through technological means. When viewed through the lens of technological innovation, it becomes clear that the early delta was colonized and transformed by singular technologies, private citizens, and loosely coordinated reclamation companies, not by coordinated top-down government planning, raising the question if this process might be employed in its re-wilding and restoration. Today, the delta is once again a frontier of the Anthropocene, having been entirely reconfigured by human agency, and now lingering on the verge of ecological collapse. Given the convergence of environmental imperatives in the delta, a reverse process of socio-technical innovation could facilitate the renewed productivity, reconstruction, and possible re-wilding of a system essential to the most urbanized state in the nation. The history of patent innovation inspired by the delta provides a timely case study for a potential future of the region that emerges as a hybrid between ecology, technology, and culture-an agglomerate of discrete inventions that re-territorialize the edge of the delta into a resilient system. They also suggest that design experiments conducted at the scale of the discrete technology may impact the larger territory, just as the levee building machines of the late nineteenth century transformed ancestral tule marshes to dry agricultural plots. 
With state budgets in perennial deficits, liquefaction looming, and sea level rise threatening high-value real estate in urban areas elsewhere in the state, at least part of the delta must go through a process of rewilding. This places two seemingly divergent conditions in a direct dialectic, that of the territory and that of the wild. If the socio-technical experiment of the Swamp Lands Act, a territorialization of California's wilderness, was used to catalyze environmental change at the scale of the delta and ultimately the urbanized region, we contend that a similar, yet inverse experiment be used to rewild the territory. The new California, and new Californians, fueled by the entrepreneurial spirit of software and start-ups, can employ their environmental imagination to consider how the environment and technology-core values of the state-could be hybridized to find synergies. The promise here is that while instigated from the bottom, these technologies are cognizant and steering their larger territorial effects. If the frontier advanced technology, can this new frontier advance nature?

\section{Notes}

1. Stephen F. Strausberg, "Indiana and the Swamp Lands Act: A Study in State Administration," Indiana Magazine of History 73, no. 3 (1977): 191-203.

2. Robert W. Harrison and Walter M Kollmorgen, "Land Reclamation in Arkansas under the Swamp Land Grant of 1850," The Arkansas Historical Quarterly 6, no. 4 (1947): 369-418.

3. Matthias Nordberg Orfield, Federal Land Grants to the States with Special Reference to Minnesota (Minneapolis: 1915).

4. Richard Mark Pintarich, "The Swamp Land Act in Oregon, 1870-1895"

(M.A. thesis, Portland State University, 1980).

5. James Oliver Wright, Swamp and Overflowed Lands in the United States. Ownership and Reclamation (Washington DC: Government Printing Office, 1907).

6. Thomas E. Dahl and Gregory J. Allord, "History of Wetlands in the Conterminous United States," National Summary on Wetland Resources (Riverside, CA, USA: USGS, 1996): 19-26. 7. Richard H. Peterson, "The Failure to Reclaim: California State Swamp Land Policy and the Sacramento Valley, 1850-1866," Southern California Quarterly 56, no. 1 (1974): 45-60. CR-Copyright (C) 1974 University of Ca., doi: https://doi.org/10.2307/41170515.

8. William L. Kahrl et al., The California Water Atlas (Sacramento, Los Altos, CA, USA: The Governor's Office of Planning and Research; distributed by William Kaufmann, 1979). 9. Frederick Jackson Turner, The Frontier in American History (New York: Henry Holt \& Co., 1920), 38.

10. Ibid., 24.

11. John Thompson, "Reclamation Sequence in the Sacramento-San Joaquin Delta" (PhD diss., University of Illinois, 1965).

12. Lawrence Buell, The Environmental Imagination: Thoreau, Nature Writing and the Formation of American Culture (Cambridge, MA, USA: Harvard University Press, 1996). 13. Richard Buckminster Fuller, Nine Chains to the Moon (London: Feffer \& Simons, 1938). 14. Richard L. Hindle, "Levees That Might Have Been," Places Journal, May 2015, https://placesjournal.org/article/levees-that-might-have-been/.

15. Nathaniel Wright Stephenson, "California and the Compromise of 1850,"

Pacific Historical Review 4, no. 2 (1935): 114-22.

16. Ibid.

17. Lewis M. Haupt, "The Galveston Harbor Problem," Journal of the Franklin Institute 132, no. 4 (1891): 275-87.

18. Richard N. L. Andrews, Managing the Environment, Managing Ourselves: A History of American Environmental Policy (Yale University Press, 1999).

19. Jason W. Moore, Capitalism in the Web of Life: Ecology and the Accumulation of Capital (Verso Books, 2015). 
20. Alan Berger, Drosscape: Wasting Land in Urban America (New York: Princeton Architectural Press, 2007).

21. Christine Alfsen, Ashley Duval, and Thomas Elmqvist, "The Urban Landscape as a Social-Ecological System for Governance of Ecosystem Services,” 2011, https://books. google.com/books?id=yxzcMhK9HdYC.

22. Nate C. Hindman and Joe Epstein, "Webster Pierce, 72-Year-Old Wave Runner Inventor, May Be the Last, Best Hope for Sinking Bayou," Huffington Post, 2013, http://www. huffingtonpost.com/nathaniel-cahners-hindman/webster-pierce-72yearold-_b_3500684.html. 23. https://www.nature.org/ourinitiatives/habitats/oceanscoasts/oyster-reef-restorationsouthern-solutions-for-a-global-problem.xml.

24. Samantha Perez, The Isleños of Louisiana: On the Water's Edge, American Heritage (Arcadia Publishing Incorporated and The History Press, 2011).

25. "Conservation Innovation Grants," https://www.nrcs.usda.gov/wps/portal/nrcs/main/ national/programs/financial/cig/.

26. "Louisiana: Restoring Oyster Reefs at Vermilion Bay," https://www.nature.org/ ourinitiatives/regions/northamerica/unitedstates/louisiana/oyster-reef-building-at-vermilionbay.xml.

27. "DredgeFest California," http://dredgeresearchcollaborative.org/works/dredgefestcalifornia/.

28. Brett Milligan et al., "DredgeFest California: Key Findings and Recommendations," 2016, http://dredgeresearchcollaborative.org/works/dredgefest-california-white-paper/.

29. Richard L. Hindle and Bhatia Neeraj, "Territorial Technologies," 2016, http://escholarship.org/uc/item/6bf831sw.

\section{References}

Alfsen, Christine, Ashley Duval, and Thomas Elmqvist. "The Urban Landscape as a SocialEcological System for Governance of Ecosystem Services," 2011.

Andrews, Richard N. L. Managing the Environment, Managing Ourselves: A History of American Environmental Policy. New Haven, CT, USA: Yale University Press, 1999, https://books.google.com/books?id=yxzcMhK9HdYC.

Berger, Alan. Drosscape: Wasting Land in Urban America. New York: Princeton Architectural Press, 2007.

Buell, Lawrence. The Environmental Imagination: Thoreau, Nature Writing and the Formation of American Culture. Cambridge, MA, USA: Harvard University Press, 1996.

Ciriacono, Salvatore. Building on Water: Venice, Holland and the Construction of the European Landscape in Early Modern Times. Oxford, UK: Berghahn Books, 2006.

Dahl, Thomas E., and Gregory J. Allord. "History of Wetlands in the Conterminous United States." National Summary on Wetland Resources, 19-26. Riverside, CA, USA: USGS, 1996.

Fuller, Richard Buckminster. Nine Chains to the Moon. London: Feffer \& Simons, 1938.

Harrison, Robert W., and Walter M. Kollmorgen. "Land Reclamation in Arkansas under the Swamp Land Grant of 1850." The Arkansas Historical Quarterly 6, no. 4 (1947): 369-418.

Haupt, Lewis M. "The Galveston Harbor Problem." Journal of the Franklin Institute 132, no. 4 (1891): 275-87.

Hindle, Richard L. "Levees That Might Have Been." Places Journal. May 2015. https://placesjournal.org/article/levees-that-might-have-been/.

- -, and Bhatia Neeraj. "Territorial Technologies," 2016. http://escholarship.org/uc/item/6bf831sw.

Kahrl, William L., et al. The California Water Atlas. Sacramento, Los Altos, CA, USA: The Governor's Office of Planning and Research; distributed by William Kaufmann, 1979.

Moore, Jason W. Capitalism in the Web of Life: Ecology and the Accumulation of Capital. Verso Books, 2015.

Nard, Craig Allen, and Andrew P. Morriss. "Constitutionalizing Patents: From Venice to Philadelphia." Review of Law and Economics 2, no. 2 (2006): 223-321.

Orfield, Matthias Nordberg. Federal Land Grants to the States with Special Reference to Minnesota. Minneapolis MN, USA, 1915.

Perez, Samantha. The Isleños of Louisiana: On the Water's Edge. American Heritage. Arcadia Publishing Incorporated, 2011. 
Peterson, Richard H. "The Failure to Reclaim: California State Swamp Land Policy and the Sacramento Valley, 1850-1866." Southern California Quarterly 56, no. 1 (April 1974): 45-60. CR-Copyright (C) 1974 University of Ca., doi:10.2307/41170515.

Pintarich, Richard Mark. "The Swamp Land Act in Oregon, 1870-1895." M.A. thesis, Portland State University, 1980.

Stephenson, Nathaniel Wright. "California and the Compromise of 1850." Pacific Historical Review 4, no. 2 (1935): 114-22.

Strausberg, Stephen F. "Indiana and the Swamp Lands Act: A Study in State Administration." Indiana Magazine of History 73, no. 3 (1977): 191-203.

Thompson, John, and Edward A. Dutra. Tule Breakers: The Story of the California Dredge. Stockton Corral of Westerners, University of the Pacific, 1983.

Thompson, John. "Reclamation Sequence in the Sacramento-San Joaquin Delta." PhD diss., University of Illinois, 1965.

Turner, Frederick Jackson. The Frontier in American History. New York: Henry Holt \& Co., 1920.

Wright, James Oliver. Swamp and Overflowed Lands in the United States: Ownership and Reclamation. Washington: Government Printing Office, 1907.

\section{Credits}

Figure 1: photo by (C) Williamson, R. S, et al., From San Francisco Bay to the northern boundary of California: from explorations and surveys, Washington, D.C., Engd. by Selmar Siebert, 1859. Map retrieved from the Library of Congress, https://www.loc.gov/item/98688433/.

Figure 2: photo by @ Doc Searls, Flickr. Creative Commons License.

Figures 3-14: public domain, www.uspto.gov

Figures 15a-15e: drawings by (c) Mario Accordino.

Richard L. Hindle is an Assistant Professor of Landscape Architecture and Environmental Planning at the University of California, Berkeley. His current research focuses on patent innovation in landscape related technologies, from large-scale mappings of riverine and coastal systems to detailed historical studies on the antecedents of vegetated architecture. His writing and making explores the potential of new technological narratives and material processes to reframe theory, practice, and the production of landscape. Recent works include "Levees That Might Have Been" in Places Journal (2015), "Infrastructures of Innovation" in Scaling Infrastructure, CAU@MIT (2016), and the exhibition Geographies of Innovation at the University of California, Berkeley (2015). E-mail: rlhindle @berkeley.edu

Neeraj Bhatia is a licensed architect and urban designer from Toronto, Canada. His work resides at the intersection of politics, infrastructure, and urbanism. He is an Assistant Professor at the California College of the Arts where he also co-directs the urbanism research lab, The Urban Works Agency. Prior to CCA, Neeraj held teaching positions at Cornell University, Rice University, and the University of Toronto. Neeraj is also founder of The Open Workshop, a transcalar design-research office. He is the co-editor of several books, such as Bracket [Takes Action] (2018), and The Petropolis of Tomorrow (2013). Neeraj has a Master degree in Architecture and Urbanism from the MIT.

E-mail: nbhatia@cca.edu 